\title{
Wędka króla Rusinów (Gall Anonim, ks. 1, rozdz. 7)
}

Zarys treści: Celem artykułu jest próba odpowiedzenia na pytanie: dlaczego Gall Anonim przedstawił króla Rusinów - postać niewojowniczą i tchórzliwą - łowiącego ryby na wędkę, w momencie ataku Bolesława Chrobrego, który przyniósł Rusi straszliwą klęskę? Użytecznego kontekstu dostarczają przypadki użycia motywu wędki i wędkujące postacie w opowieściach, których Gall Anonim na pewno nie znał: Le roman de Perceval ou le conte du Graal Chrétiena de Troyes (Król-Rybak), Żywot Antoniusza Plutarcha z Cheronei, Waltharius, opowiadanie o zdobyciu Rzymu przez Arnulfa w Antapodosis Liudpranda z Cremony, opowieść o Wandzie w Kronice wielkopolskiej oraz historia uzdrowienia córki cesarza Galiena przez św. Zenona z Werony w De Zenonis vita sermo Coronati Notarii.

\begin{abstract}
The purpose of the article is to answer the question why did Gallus Anonymus present the king of the Ruthenians - the unwarlike and cowardly man - fishing with a fishing rod at the moment of Boleslaw Chrobry's attack which inflicted a catastrophic defeat upon Rus'? A useful context is given by motif of fishing rod and fishing people in stories unknown to Gallus Anonymus: Le roman de Perceval ou le conte du Graal by Chrétien de Troyes (the Fisher King), Plutarch's Life of Antony, Waltharius, the story about Arnulf conquering Rome in the Antapodosis by Liudprand of Cremona, the story about Wanda in the Chronica Poloniae maioris (Chronicle of Greater Poland), and the story about the restoration to health of Emperor Gallienus's daughter by Saint Zeno of Verona in De Zenonis vita sermo Coronati Notarii.
\end{abstract}

Stowa kluczowe: Gall Anonim, król Rusinów, wędka, królewskie wędkowanie, Król-Rybak, Plutarch, Antoniusz, Waltharius, Liudprand z Cremony

Keywords: Gallus Anonymus, king of Ruthenians, fishing rod, royal angling, The Fisher King, Plutarchos, Antony, Waltharius, Liudprand of Cremona

W siódmym rozdziale pierwszej księgi swojego dzieła Gall Anonim opowiedział, jak chwalebnie i wspaniale Bolesław Chrobry pokonał Ruś. Była to zemsta na królu Rusinów, który nie chciał wydać swojej siostry za polskiego władcę. Bolesław wkroczył z wielkim wojskiem do królestwa ruskiego i niczym wiatr rozwiewający pył, zbrojnie zmiótł tych, którzy początkowo próbowali mu się przeciwstawić. Nie tracił czasu na zdobywanie grodów i zbieranie łupów, lecz podążył prosto do Kijowa, stolicy królestwa, aby zająć pałac królewski i pojmać wroga. W tym momencie Anonim przeniósł swoją uwage na zaatakowanego. „At Ruthenorum rex simplicitate gentis illius in navicula tunc forte cum hamo piscabatur, cum Bolezlauum adesse regem ex insperato nuntiant. Quod ille vix credere potuit, sed tandem aliis et aliis sibi nuntiantibus certificatus exhorruit. Tunc demum pollicem simul et indicem ori porrigens, hamumque sputo more piscatorum liniens, in ignominiam sue gentis proverbium protulisse fertur: Quia Bolezlauus huic arti non studuit, sed arma militaria baiolare consuevit, idcirco Deus in manum eius tradere civitatem istam regnumque Ruthenorum et divitias destinavit. Hec dixit, nec plura 
prosecutus fugam arripuit"'. Tak skończył się pierwszy występ króla Rusinów na kartach kroniki Galla i dziejopisarz przystąpił do opowiadania o wkroczeniu Bolesława Chrobrego do Kijowa.

Zacytowany fragment jest wyraźnie wyodrębnioną częścią opowieści o pierwszej (w kronice Anonima) wyprawie polskiego władcy na Ruś. Ogólna wymowa passusu wydaje się jednoznaczna. Przeciwnik Bolesława został przedstawiony jako jego przeciwieństwo. Wyróżniony jest aspekt militarny tego przeciwstawienia. Król Rusinów był niewojowniczy, tchórzliwy i całkowicie zaskoczony najazdem. W związku z tym pogodził się z koniecznością oddania własnej stolicy, królestwa i bogactw w ręce wroga, a następnie uciekł. Dlaczego w Gallowej opowieści wędka znalazła się w ręku tak wymodelowanej postaci? Na to pytanie będę starał się odpowiedzieć w niniejszym tekście.

Wędkowanie wpisuje się w ogólniejszą ramę sprawdzania monarszych kwalifikacji królów, któremu poświęcony jest cały rozdział siódmy pierwszej księgi kroniki Anonima. Władca Rusinów uważał się za lepszego od Bolesława i dlatego nie oddał mu siostry. Wynik wojny dowiódł, jak dalece nie miał racji. Po zajęciu Kijowa przez Polaków siostra tchórzliwego króla nie była już godna zostać żoną Chrobrego. Polski monarcha wziął ją na jedną noc, jako nałożnicę. Uczynił tak, aby pomścić zniewagę własnego rodu i upokorzyć Rusinów². Łowieniu ryb na wędkę Gall kazał odegrać bardzo istotną rolę w tej opowieści. Bóg oddał Chrobremu królestwo ruskie właśnie dlatego, że polski król nie znał sztuki wędkowania. Zamiast tego miał zwyczaj nosić broń stosowną na wojnie. Zatem król Rusinów przegrał między innymi z powodu wędki i obyczaju rybaków, który praktykował. Ta konstatacja zachęca do uważnego i osobnego przyjrzenia się znaczeniu przedmiotu i związanej z nim czynności, skoro tak wiele znaczą w Gallowej narracji.

Interpretacje tego szczegółu z kroniki Anonima pojawiające się w literaturze naukowej są ogólnikowe i zdawkowe. Zacznę od tych, które wydają się oczywiste. Od nich przejdę to takich, z którymi nie można się zgodzić. Aleksander Gieysztor uważał, że negatywną ocenę zajęcia ruskiego króla „złożyć wypada na zachodnioeuropejską wizję kronikarza tego, czym władcy zajmować się godzi"3. Z kolei Andrzej Feliks Grabski dostrzegł w Gallowej wypowiedzi zamiar tendencyjnego ośmieszenia Rusina ${ }^{4}$. Trudno nie podzielać tych opinii. Pozostają pytania. Dlaczego łowienie ryb na wędkę uwłaczało zachodnim monarchom i ich ośmieszało? Czy takie postrzeganie jest specyficzne dla zachodnioeuropejskiego średniowiecza? Edward Skibiński odniósł się do sprawy równie lakonicznie: „Wędkowanie władcy jest może elementem kolorytu »orientalnego«, w którym wszystko jest na opak. Przypomnijmy, że króla-rybaka spotykamy w średniowiecznych narracjach"s. Spróbuję sprawdzić w dalszej części niniejszych rozważań i „orientalizm”, i czy „wszystko jest na opak” w Gallowej opowiastce o wędkującym władcy, a także jego ideowe związki z Królem-Rybakiem.

Na ciekawy aspekt wypowiedzi Anonima o monarsze z wędką zwrócił uwagę Wojciech Polak: „Cechą postępowania ruskiego władcy jest simplicitas. Wyraz ten ma znaczenie, z naszego punktu widzenia, ambiwalentne. $Z$ jednej strony oznacza prostotę, a więc cechę wartościowaną w kręgu chrześcijańskim pozytywnie, z drugiej zaś naiwną głupotę, czyli cechę przeciwstawianą do sapientia. Kontekst, w którym występuje to słowo w analizowanym obecnie fragmencie Kroniki, dopuszcza możliwość obu

\footnotetext{
1 Anonima tzw. Galla kronika czyli dzieje książąt i władców polskich, wyd. K. Maleczyński, w: MPH s.n., t. 2, Kraków 1952, ks. 1, rozdz. 7, s. 22 [dalej: Gall Anonim]; pol. tłum., trochę przeze mnie zmodyfikowane (zmiany zaznaczam pogrubieniem) za: Anonim tzw. Gall, Kronika polska, tłum. R. Grodecki, oprac. M. Plezia, wyd. 7, Wrocław-Warszawa-Kraków 1999 [dalej: Grodecki/Plezia], s. 23: „A król Rusinów, z prostotą właściwą temu ludowi, wówczas przypadkiem łowił z lódki ryby na wędkę, gdy mu niespodziewanie doniesiono o nadejściu króla Bolesława. Zrazu nie mógł w to uwierzyć, lecz nareszcie, gdy mu to jedni za drugimi donosili, przekonał się i wpadł w przerażenie. Wtedy dopiero włożył do ust kciuk i palec wskazujący i obyczajem rybaków pomazując śliną haczyk, mówi się, że takie słowa wygłosil na hańbę swojego ludu: Ponieważ Bolesław tej sztuki nie uprawiał, lecz miał zwyczaj nosić broń potrzebną na wojnę, dlatego Bóg postanowił wydać w jego ręce to miasto, królestwo Rusinów i bogactwa. To rzekł i nie tracąc słów więcej, rzucił się do ucieczki”.

2 Gall Anonim, ks. 1, rozdz. 7, s. 23.

3 A. Gieysztor, Obraz Rusi w Polsce średniowiecznej, w: tenże, O dziedzictwie kultury, Warszawa 2000, s. 71.

${ }^{4}$ A.F. Grabski, Polska w opiniach obcych X-XIII w., Warszawa 1964, s. 45; podobnie zob. P. Borek, Szlakami dawnej Ukrainy. Studia staropolskie, Kraków 2002, s. 52, przyp. 17.

${ }^{5}$ E. Skibiński, O metodach badania narracji w kronikach średniowiecznych, Kwart. Hist., 118, 2011, nr 2, s. 286.
} 
interpretacji”. W dalszym ciągu swojego wywodu W. Polak rozstrzygnął jednak ten dylemat. Posłużył się zwrotem „puerilis simplicitas”, który Gall Anonim w trzeciej księdze kroniki odniósł do najmłodszego brata wygnanego czeskiego księcia Borzywoja (czyli do Sobiesława, którego imię nie pada w kronice $)^{7}$ i uznał, że prostotę króla Rusinów „rozumieć należy w znaczeniu pejoratywnym”. Sprawa nie jest taka prosta. Bardziej adekwatna wydaje się pierwsza diagnoza W. Polaka, wskazująca na ambiwalencję pojęcia „simplicitas”. Z pewnością nie da się przypisać królowi Rusinów „naiwnej głupoty”. Uważna lektura badanego opowiadania Anonima pozwala bowiem zauważyć, że to wędkujący monarcha ogłosił wyrok Boży, oddający jego królestwo pod władzę Bolesława. Ponadto ruski władca, w dalszej części rozdziału, trafnie przewidział osłabienie przeciwnika w trakcie powrotu do Polski i właśnie wtedy postanowił zaatakować Polaków od tyłu9. Jako wojownika kompromituje go to równie mocno jak uprzednia ucieczka ${ }^{10}$. Jednocześnie dowodzi, że antagonista Chrobrego, choć niewątpliwie tchórzliwy i niebohaterski, jest także rozumny i przebiegły.

Chybiona wydaje się opinia Stefana M. Kuczyńskiego. W Gallowej wypowiedzi dopatrywał się on ironii, użytej pod adresem ruskiego władcy dlatego, że Jarosław Mądry uzurpował sobie tron kijowski, należny zięciowi Bolesława Chrobrego ${ }^{11}$. Jeżeli ironię rozumieć jako sprzeczność między literalną treścią tekstu a znaczeniem zamierzonym przez autora, to nie da się uznać opowiadania Anonima za ironiczne. Co więcej, zupełnie błędne jest historyczne wythumaczenie genezy Gallowego wizerunku ruskiego władcy. Nic nie wskazuje na to, że kronikarz znał szczegóły i protagonistów bratobójczej wojny o schedę po Włodzimierzu Wielkim. Nawet samo nazywanie postaci z kroniki Anonima Jarosławem Mądrym jest nadinterpretacją.

W komentarzach do opowiadania o wędkowaniu króla Rusinów pojawił się nurt „etnograficzny”. Karol Maleczyński, przygotowując edycję kroniki, odniósł do tego passusu cztery przypisy rzeczowe. Ostatnie dwa dotyczą nietrafnych - moim zdaniem - paraleli biblijnych dla dwóch zwrotów ${ }^{12}$. W pierwszym odnośniku wydawca spostrzegł: „unde hanc fabellam de Ruthenorum duce piscatore sumpserit auctor non liquet”13. Celnie uznał tym samym - co przy okazji godne podkreślenia - że „fabella de piscatore” jest osobną całością. W kolejnym przypisie stwierdził trwanie obyczaju ślinienia haczyka (a precyzyjniej, nadzianej nań przynęty, a później złowionej ryby) aż po XX w. Na poparcie przywołał dwie prace Marii Znamierowskiej-Prüfferowej o rybołówstwie na jeziorach trockich i w okolicach Druskiennik ${ }^{14}$. Jak rozumieć takie stwierdzenie? Trzeba spekulować, K. Maleczyński nie rozwinął bowiem owej myśli. Sądzę, że starał się w ten sposób dowieść wiarygodności Galla. Kronikarz - zdaniem K. Maleczyńskiego - znał obyczaj rybaków, skoro opisane przezeń zachowania uchwytne były w XX w. u wędkarzy na

${ }^{6}$ W. Polak, Kronika Galla Anonima a pochodzenie rodu Awdańców, w: Peregrinatio ad veritatem. Studia ofiarowane profesor Aleksandrze Witkowskiej OSU z okazji 40-lecia pracy naukowej, red. U. Borkowska, C. Deptuła, R. Knapiński, Z. Piłat, E. Wiśniowski, Lublin 2004, s. 411.

7 Gall Anonim, ks. 3, rozdz. 21, s. 147.

8 W. Polak, Kronika Galla Anonima a pochodzenie rodu Awdańców, s. 411.

9 Gall Anonim, ks. 1, rozdz. 7, s. 24.

${ }_{10}$ P. Żmudzki, Władca $i$ wojownicy. Narracje o wodzach, drużynie $i$ wojnach $w$ najdawniejszej historiografii Polski $i$ Rusi, Wrocław 2009, s. 35-38.

${ }^{11}$ S.M. Kuczyński, Stosunki polsko-ruskie do schyłku wieku XII, w: tenże, Studia z dziejów Europy Wschodniej X-XVII w., Warszawa 1965, s. 31.

${ }^{12}$ Gall Anonim, s. 22, przyp. 8 i 9. K. Maleczyński skojarzył „in ignominiam sue gentis” z sentencją z Księgi Przysłów $(17,21)$ : „Natus est stultus in ignominiam suam”. Sądzę, że nie ma jednak podstaw, by zakładać, że Anonim wzorował się na biblijnym przysłowiu. Podobnie w drugim przypadku. Zwrot ,idcirco Deus in manum eius tradere” został zestawiony ze zdaniem z 1 Księgi Samuela (24,29): „quomodo tradiderat me deus in manum tuam”. I ten zwrot Gall raczej skonstruował samodzielnie. Brakuje fabularnej zbieżności sytuacji króla Rusinów i Saula, który wypowiedział zacytowane słowa. Jest to fragment opowieści o tym, jak Dawid zakradł się do jaskini, w której spał król. Jednak nie zabił go, a jedynie obciął skraj królewskiego płaszcza i następnie z daleka poinformował o tym Saula. Król dzięki temu zrozumiał, że Dawid nie żywi złych zamiarów. W czasie, kiedy powstawał niniejszy artykuł, Kajetan Stobiecki napisał pod moim kierunkiem pracę licencjacką pt.: Cytaty biblijne w Kronice Galla Anonima.

${ }^{13}$ Gall Anonim, s. 22, przyp. 6.

14 Tamże, przyp. 7. 
Litwie. Nawet jeśli wziąć tę sugestię za dobrą monetę, to nie thumaczy ona najważniejszego (przynajmniej dla mnie): dlaczego Gall uważał wędkowanie za zajęcie niewojownicze? Idee „etnograficznego” komentarza K. Maleczyńskiego podjęli Paul W. Knoll i Frank Schaer, thumacze kroniki Anonima na język angielski. Powołali się oni na pracę Richarda C. Hoffmanna, w której - ich zdaniem - można znaleźć szczegóły podobne do Gallowych, wzięte z późnośredniowiecznych poradników dla rybaków ${ }^{15}$.

Tropem tego wątku poszedł Karol Kollinger, okraszając przykłady zaczerpnięte od M. Znamierowskiej-Prüfferowej połowem okoni u Kaszubów. Następnie celnie zauważył, że porady dla rybaków wskazane przez wydawców łacińsko-angielskojęzycznej edycji kroniki Anonima nie mają nic wspólnego z Gallową opowiastką. W tym miejscu K. Kollinger porzucił interpretację „etnograficzną” i podążył w innym kierunku: „Sam fakt łowienia ryb w łodzi przez Jarosława Mądrego, w politycznie istotnym momencie, przywołuje zaś na myśl anegdotę dotyczącą cara Aleksandra III”, który odmówił przerwania wędkowania w celu udzielenia audiencji posłowi obcego mocarstwa, mówiąc: „Kiedy car rosyjski łowi ryby, Europa może poczekać" ${ }^{16}$. Anegdota przytoczona przez K. Kollingera dostarcza znakomitej okazji do wygłoszenia kilku uwag na temat metody komparatystycznej. W Gallowym passusie wyjaśnienia wymaga uwłaczający charakter wędkowania, ściśle powiązany z niewojowniczą osobowością króla Rusinów. Zatem fabularne podobieństwo opowiastki Anonima i anegdoty o carze (w obu wypadkach władca łapie ryby, a posłańcy odrywają go od tej czynności) z takiej perspektywy badawczej nie mają większego znaczenia. Dumna wypowiedź Aleksandra III i jej okoliczności niosą bowiem ze sobą inne przesłanie niż passus Gallowy. Car w swoim mniemaniu był tak wielki i potężny, że nie musiał porzucać choćby najbłahszej rozrywki dla najważniejszego nawet poselstwa z Europy. Łowienie ryb, pozbawione w tym wypadku wojennego kontekstu, nie hańbiło Aleksandra III. Wręcz przeciwnie, dało okazję, aby pokazać Europie, gdzie jej miejsce. Natomiast Gallowy król Rusinów, zajęty wędkowaniem, zupełnie nie wiedział, że nadszedł dla niego ,politycznie istotny moment”. Kronikarz kunsztownie podkreślił to za pomocą retardacji. Ruski władca nie mógł uwierzyć kolejnym osobom zawiadamiającym go o ataku Polaków, ponieważ dał się całkowicie zaskoczyć.

Daleko idące generalizacje oparł o Gallową opowiastkę Witold Hensel: „Z relacji tej, świadomie chyba fałszywej w odniesieniu do Rusi, widać, że łowienie ryb w XII wieku nie uchodziło w Polsce za czynność, którą mógłby się zajmować ktoś należący do góry feudalnej. Pogardliwe odezwanie się Galla o wspomnianym zajęciu wyraźnie wskazuje, że rybołówstwem trudnić się musieli ludzie z warstw niższych oraz że zróżnicowanie klasowe ówczesnego społeczeństwa polskiego było już zupełnie wyraźne"17. Te interpretacje nie wydają się uzasadnione. Przekonanie Anonima, że Chrobry nie imał się wędki jest elementem ideału władcy, który zakładał skrajny ekskluzywizm zachowań króla. Bolesław I, w całym poświęconym mu fragmencie kroniki, jawi się jako postać konsekwentnie odróżniona od swoich poddanych i innych władców. Jest bowiem od nich znacznie lepszy, mądrzejszy, dostojniejszy, mężniejszy i wspanialszy. Ta zasada konstrukcji wizerunku Chrobrego nie zachęca do szybkiego i łatwego przenoszenia przypisanego królowi braku umiejętności na całą „górę feudalną”. Co do „zróżnicowania klasowego", W. Hensel nie zauważył, że odium dotyka wędkującego władcę tylko w opowiadaniu Galla. Według Kadłubka i Jana Długosza łapanie ryb na wędkę jest błahą, ale niehańbiącą rozrywką (o czym dalej). Gdyby więc konsekwentnie stosować interpretację Hensla, trzeba by założyć, że na początku XII w. „Zróżnicowanie klasowe” było większe niż u schyłku tego stulecia oraz w XV w.

Jak zatem badać znaczenie wędki w passusie Gallowym? Warto wyjść poza interpretacje oczywiste, a także zrezygnować z intuicji prowadzących na manowce. Najpierw postawię tezę. Następnie przeprowadzę cztery odrębne procedury badawcze: 1) przyjrzę się biblijnym kontekstom wędki i ewentualnym inspiracjom płynącym z literatury klasycznej, czyli temu, co stanowiło (a przynajmniej mogło

15 Gallus Anonymus, Gesta Principum Polonorum, tłum. i oprac. P.W. Knoll, P. Schaer, wstęp T.N. Bisson, Budapest-New York 2003, s. 41, przyp. 5.

16 K. Kollinger, Polityka wschodnia Bolestawa Chrobrego (992-1025), Wrocław 2014, s. 309-310, przyp. 464 (cyt. zdanie na s. 310).

${ }^{17}$ W. Hensel, Słowiańszczyzna wczesnośredniowieczna. Zarys kultury materialnej, wyd. 2 popr. i uzup., Warszawa 1956, s. 137. 
stanowić) intelektualne zaplecze kronikarza; 2) przeanalizuję średniowieczne przeróbki „fabułki” Anonima; 3 ) rozważę szczegóły królewskiego wędkowania w kontekście innych opowieści w kronice Galla; 4) skonfrontuję badany passus ze średniowiecznymi opowieściami, w których motyw wędki występuje zupełnie niezależnie. Czwarty krok będzie najważniejszy. Zdecyduje o rozpoznaniu sensu anegdoty.

Nie sposób rozstrzygnąć, czy Gall Anonim korzystał z jakiejś starszej tradycji, pisząc o łowieniu ryb przez króla Rusinów, czy sam skonstruował tę opowiastkę ${ }^{18}$. Nie jest to także czczy element „małego realizmu”, jak zdają się uważać zwolennicy interpretacji „etnograficznej”. Nic sensownego nie da się też powiedzieć o historyczności tego epizodu wojny polsko-ruskiej ${ }^{19}$. Nie ma to dla mnie większego znaczenia, ponieważ zakładam - i to jest właśnie moja teza - że wędka pojawiła się w ręku przeciwnika Chrobrego celowo. Jest ona przewrotnym atrybutem króla Rusinów ${ }^{20}$. Nawet jeśli została przejęta z uprzedniej opowieści (ustnej?) - czego nie da się potwierdzić ani wykluczyćc ${ }^{21}$ - to nie bezrefleksyjnie i nie tylko z uwagi na barwność szczegółu. W każdym razie sens wędkowania w kronice Anonima jest uchwytny wyłącznie w kontekście opowiadania o triumfalnym wkroczeniu Bolesława na Ruś. Wskazuje na to charakterystyczny zabieg narracyjny. Król Rusinów „przypadkiem” łowił ryby na wędkę w momencie polskiego ataku. Nie ma nic bardziej nieprzypadkowego niż „przypadek” w kronice Anonima. Dość przypomnieć, że podobne zrządzenie losu (forte fortuna) zdecydowało o przybyciu tajemniczych wędrowców do ubogiej chatki oracza Piasta ${ }^{22}$. Wielka kariera rodu Bolesława Krzywoustego - jeden z głównych tematów Gallowego dzieła - zaczęła się „przypadkiem”"23. Będę więc wędkę traktował jako przedmiot znaczący. Jest ona dopełnieniem charakterystyki dzierżącej ją postaci.

Zacznę od Biblii, idąc tropem przekonania - w odniesieniu do kroniki Galla Anonima najpełniej wyrażonego przez Czesława Deptułę ${ }^{24}$ o jej dominującym wpływie na wyobrażenia i konstrukcje fabularne kronikarza. W przypadku wędki króla Rusinów takie założenie się nie sprawdza. W Piśmie Świętym łowienie ryb - przede wszystkim za pomocą sieci - ma oczywiście ogromne znaczenie symboliczne, inne jednak niż u Galla. Wystarczy przywołać słynne passusy ewangeliczne o okolicznościach powołania Szymona-Piotra, Andrzeja, Jakuba i Jana czy o cudownym połowie ryb ${ }^{25}$, który prefigurował zadanie wyznaczone apostołom przez Jezusa: „faciam vos fieri piscatores hominum”26. W Ewangelii

${ }^{18}$ Formułowano na ten temat ostre, skrajne i niczym niepoparte poglądy: A. Brückner, Legendy i fakty. Szkice z dziejów literatury, Łódź 1931, s. 20: „te wszystkie anegdoty o kuchcikach, co Ruś pobili, o »królu« ruskim i rybiej wędce itd., te anegdoty nie tradycja mu dała, te zmyślił dopiero Węgier [czyli Gall Anonim - P.Ż.] sam, jak i ową iście Mikoszową pornografję o złotej bramie i o Przedsławie”. Tak samo gołosłowne jest przekonanie E. Skibińskiego (tenże, „Vindicatio” władców Polski w zwierciadle kronik Anonima tzw. Galla i mistrza Wincentego, w: Kościót w monarchiach Przemyślidów i Piastów, red. J. Dobosz, Poznań 2009, s. 370), że: „Mamy tu do czynienia z konstrukcją narracyjną, która wydaje się być starsza od samego tekstu Anonima".

${ }_{19}$ M. Plezia, Kronika Galla na tle historiografii XII wieku, Kraków 1947, s. 79. Jak z rozbrajającą stanowczością stwierdził T. Grudziński: „Cały dalszy fragment tekstu od słów: At Ruthenorum rex... do ...nec plura prosecutus fugam arripuit z punktu widzenia jego wartości źródłowej jest bez znaczenia”; tenże, Ze studiów nad kronika Galla. Rozbiór krytyczny pierwszej księgi. Dokończenie, Zap. Hist., 23, 1957, z. 1, s. 42.

20 J. Banaszkiewicz, Atrybuty i społeczne „ordines”. Kilka obrazków z X-XI wieku, w: tenże, Trzy po trzy o dziesiątym wieku, Kraków 2014, s. 221-240; tenże, „Zamach stanu w Gnieźnie”, czyli kilka uwag do drugiego wydania książki „Podanie o Piaście i Popielu”, w: tenże, Podanie o Piaście i Popielu. Studium porównawcze nad wczesnośredniowiecznymi tradycjami dynastycznymi, wyd. 2, Warszawa 2010, s. 18: „Niewłaściwy atrybut trafia bowiem w niewłaściwe ręce, akcja nie będzie skrojona na miarę możliwości postaci, wbrew temu, co się od bohatera oczekuje i co robić powinien”.

${ }^{21}$ Przytoczone przez T. Grudzińskiego opinie Iwana Linniczenki (jakoby Gall wykorzystał pieśni ludowe), Władimira Mawrodina (o poetyckiej inwencji uczestników wyprawy kijowskiej) oraz jego własny pogląd („,Opowieść nosi bowiem niewątpliwe cechy baśni opartej na motywach ludowych i daleko odbiega od anegdotycznych amplifikacji pióra kronikarza z księgi III”) są swobodnymi spekulacjami; T. Grudziński, Ze studiów nad kroniką Galla, s. 42-43.

22 Gall Anonim, ks. 1, rozdz. 1, s. 9.

${ }^{23}$ J. Banaszkiewicz, ,Zamach stanu w Gnieźnie”, s. 22-23.

${ }^{24}$ C. Deptuła, Galla Anonima mit genezy Polski. Studium z historiozofii i hermeneutyki symboli dziejopisarstwa średniowiecznego, wyd. 2, Lublin 2000

${ }_{25}$ Mt 4,18-22; Mc 1,16-20; Lc 5,1-7; Io 21,1-11.

${ }^{26}$ Mc 1,17. Biblia sacra iuxta Vulgatam versionem, wyd. 3, Stuttgart 1985, t. 2, s. 1575: „uczynię, że staniecie się rybakami łowiącymi ludzi" [tłum. P.Ż.]. 
św. Mateusza do sieci pełnej ryb porównane zostało Królestwo Niebieskie, przy czym połów i selekcja złowionych okazów symbolizuje Sąd Ostateczny ${ }^{27}$. Eschatologiczny sens porównania wyrasta z fatalnej konotacji sieci w Biblii ${ }^{28}$. W Psalmach, księgach mądrościowych i prorockich jest bardzo często przywoływaną metaforą śmiertelnego niebezpieczeństwa, pułapki, zagrożenia, od których wybawić może tylko Pan. Powtarza się wielokrotnie motyw złoczyńców wpadających we własne sieci, zastawione na podmiot wypowiadający się w tekście ${ }^{29}$.

Takie same skojarzenia uchwytne są w odniesieniu do znacznie rzadziej występującego w Wulgacie słowa „hamus”, oznaczającego i „haczyk”, i „wędkę”. W literaturze rzymskiej naszej ery nabiera ono treści metaforycznej: „pokusa”, „podstęp”, „zasadzka” ${ }^{0}$. Ten kontekst nieobcy był św. Hieronimowi. W Wulgacie najmocniej wyraża go cytat z Księgi Eklezjasty: „nescit homo finem suum sed sicut pisces capiuntur hamo et sicut aves conprehenduntur laqueo sic capiuntur homines tempore malo cum eis extemplo supervenerit" ${ }^{\prime 1}$. Nie da się jednak rzutować takiego znaczenia wędki na opowiastkę Galla. Tym bardziej trzeba wykluczyć wpływ innych fragmentów biblijnych. Trudną do zrozumienia rolę wędka odgrywa w Księdze Hioba. Słowo „hamus” pojawia się w opowieści o Behemocie, który wypije rzekę Jordan, a następnie ,in oculis eius quasi hamo capiet eum" ${ }^{32}$. Tekst jest w tym miejscu niejasny. Nie wiadomo, do czego odnieść zaimki i w związku z tym nie da się rozstrzygnąć, o czyje oczy chodzi i kto kogo złapie na hak. „Hamus” występuje też w następnym wersie, w którym pada pytanie, czy można złapać Lewiatana na wędkę i związać sznurem jego język. Passus ten stał się punktem wyjścia wielkiej tradycji egzegetycznej. W najsłynniejszym bodaj komentarzu Grzegorza Wielkiego do Księgi Hioba Behemot i Lewiatan uosabiają siły zła, dążące do wygubienia rodzaju ludzkiego. Bóg natomiast z własnego syna uczynił przynętę, dzięki której zło złapane zostanie na wędkę ${ }^{33}$. Z pewnością soteriologiczna interpretacja Grzegorza Wielkiego nie miała wpływu na Gallowa opowieść o królu Rusinów. Jeżeliby natomiast szukać dosłownego sensu, wyrażonego w drugim zdaniu, w którym w Księdze Hioba pojawiła się wędka (Hi 40,20), to polega on chyba na przekonaniu o niemożności złapania potężnego Lewiatana czymś, co służy do łowienia ryb. W Księdze Izajasza, w proroctwie o plagach, które spadną na Egipt, prorok zapowiedział m.in. wyschnięcie morza i rzek. Nieszczęście to zasmuci rybaków łowiących na wędkę i siecią ${ }^{34}$. Nieco bardziej złożony przekaz pojawił się w przepowiedni Habakuka. Prorok zwrócił się do Pana, który postanowił ukarać Izrael i posłać nań Chaldejczyków. „Et facies homines quasi pisces maris et quasi reptile non habens principem totum in hamo sublevavit traxit illud in sagena sua et congregavit in rete suo super hoc laetabitur et exultabit propterea immolabit sagenae suae et sacrificabit reti suo quia in ipsis incrassata est pars eius et cibus eius electus propter hoc ergo expandit sagenam suam et semper interficere gentes non parcet" ${ }^{\prime 35}$. Wędka i sieci obrazują u Habakuka

27 Mt 13,47-50

28 W Wulgacie: „rete”, „retia”, „sagena”, i nie chodzi o sieć wyłącznie do chwytania ryb, ale wszelkiej zdobyczy.

29 Na przykład: Ps 9,16; Ps 9,30; Ps 30,5; Ps 34,7-8; Ps 56,7; Ps 140,9-10; Prv 1,17; Lm 1,13; Ez 12,13; Ez 17,20; Ez 19,8; $\mathrm{Oz} 5,1$.

$30<$ http://logeion.uchicago.edu/index.html\#HAMUS> [dostęp 21.04.2015]. W takim znaczeniu Wincenty Kadłubek użył słowa „hamus”, pisząc o Zbigniewie: „Itaque sub amoris pretextu tendit laqueos, fodit pedicas, torquet pendilia, casses iacet, hamos inescat, amenta toxicat et omne dolositatis artificium experitur"; Mistrza Wincentego zwanego Kadtubkiem kronika polska, wyd. M. Plezia, MPH s.n., t. 11, Kraków 1994, ks. 2, rozdz. 28, s. 75. Inne przykłady i znaczenia: Słownik łaciny średniowiecznej w Polsce, <http://scriptores.pl/elexicon/dostep/singleView.html?what=HAMUS\#haslo_pelny> [dostęp 21.04.2015].

31 Ecl 9,12. Biblia sacra iuxta Vulgatam versionem, t. 2, s. 994: „nie zna człowiek swojego końca, lecz jak ryby są łapane wędką i jak ptaki chwytane są w sidła, tak ludzie są brani w zły czas, gdy na nich znienacka przyjdzie" [tłum. P.Ż.]. Co znamienne, Septuaginta mówi w tym miejscu o łowieniu ryb siecią; Septuaginta, tłum. R. Popowski SDB, wyd. 2, Warszawa 2014, s. 1074.

32 Hi 40,19. Biblia sacra iuxta Vulgatam versionem, t. 1, s. 764.

33 Moralia in Iob: <http://www.lectionarycentral.com/GregoryMoralia/Book33.html> [dostęp 22.04.2015].

34 Iz 19,8.

35 Hab 1,14-15. Biblia sacra iuxta Vulgatam versionem, t. 2, s. 1409: ,i uczynisz ludzi jakby rybami morskimi i jakby płazami nie mającymi władcy. Wszystko wędką wydobył, wyciągnął w sieci swojej i zgromadził w sieci swojej, dlatego cieszyć i radować się będzie, dlatego złoży w ofierze sieci swoje i uświęci sieć swoją, ponieważ w nich powiększyła się część jego i doborowy pokarm jego, dlatego rozciągnął sieć swoją i nie przestaje zabijać ludy" [tłum. P.Ż.]. 
ogromną przewagę militarną Babilonu, której Izrael, niczym ryba bądź płaz, nie będzie się w stanie przeciwstawić. To zupełnie odwrotnie niż u Galla. Ważne jednak dla mojego dalszego wywodu jest to, że w proroctwie Habakuka nie ma żadnej różnicy między symboliką łowienia ryb wędką i siecią. Wędkowanie zostało też zamieszane w opowiadanie o cudzie zapowiedzianym przez Jezusa w Ewangelii św. Mateusza. Także i ten fragment Pisma Świętego nie ma związku z opowiastką o królu Rusinów. W Kafarnaum do św. Piotra przystąpili poborcy dwudrachmy, żądając podatku od niego i jego Mistrza. Chrystus uważał wprawdzie, że opłata jest nienależna, ale nie chcąc urazić kwestorów, kazał Piotrowi zarzucić wędkę na morzu. W pierwszej wyłowionej rybie miał się znajdować stater, którym Piotr miał zapłacić podatek ${ }^{36}$.

Ciekawszy od przykładów biblijnych wydaje się przypadek wędkowania pojawiający się w Swetoniuszowym żywocie Augusta. W tej jego części, w której charakteryzowane są obyczaje, wygląd i cechy osobowości princepsa, biograf umieścił następujący opis: „Exercitationes campestres equorum et armorum statim post ciuilia bella omisit et ad pilam primo folliculum que transiit, mox nihil aliud quam uectabatur et deambulabat, ita ut in extremis spatiis, subsultim decurreret sestertio vel lodicula inuolutus. Animi laxandi causa modo piscabatur hamo, modo talis aut ocellatis nucibus que ludebat cum pueris minutis, quos facie et garrulitate amabilis undique conquirebat, praecipue Mauros et Syros. Nam pumilos atque distortos et omnis generis eiusdem ut ludibria naturae mali que ominis abhorrebat" ${ }^{37}$. Nie ma najmniejszej wątpliwości, że u Swetoniusza wędkowanie nie hańbi Augusta. Jest ono po prostu nieistotną rozrywką zestawioną z zabawami małych chłopców. Znamienne jest jednak przejście od wojskowego treningu z czasów wojen domowych do gier i krotochwilnych zajęć okresu pokoju. Pamiętając o tym, przystępuję do przeglądu średniowiecznych przeróbek Gallowej opowiastki o ruskim władcy łowiącym ryby. Nie będzie on długi, ponieważ tylko dwóch autorów podjęło ten wątek: Kadłubek i Jan Długosz.

Mistrz Wincenty inaczej niż Anonim rozłożył szczegóły opowieści o Bolesławie Chrobrym. Zdobycie Kijowa dołączył do ogólnej prezentacji militarnych triumfów polskiego władcy i uderzenie mieczem w Złotą Bramę zinterpretował jako wycięcie znaku granicznego na wschodnim krańcu imperium. Chrobry nie został w ruskiej stolicy na stałe, lecz: „Vbi quendam sui sanguinis regem creat, ipso Ruthenorum rege non prelio quidem, sed solo ignauie metu profligato. Nam cum illi imminere nuntiatur, ut erat nugis piscationum intentissimus, hamum cum regno abicit dicens: Eius hamo sumus intercepti, qui siluros prendere non didicit. Quo uix dicto in fugam tremebundus conuertitur, fuga tutior quam belli congressu felicior"38. Kadłubek dość wiernie odtworzył Gallową konstrukcję postaci króla Rusinów. Tchórz, który nie odważył się wydać bitwy Bolesławowi, postradał swoje królestwo właściwie na własne życzenie. Natomiast wędkowanie zostało przez Wincentego sprowadzone - wbrew Gallowi - do

36 Mt 17,23-26.

37 Suetonius, De uita Caesarum, Diuus Augustus, wyd. M. Ihm, Leipzig 1908, rozdz. 83; pol. thum. za: Gajus Swetoniusz Trankwillus, Żywoty Cezarów, tłum. J. Niemirska-Pliszczyńska, wyd. 6, Wrocław-Warszawa-Kraków 1987, s. 120-121: „Ćwiczeń polowych w zakresie jazdy konnej lub władania bronią poniechał wnet po wojnach domowych. Przeszedł do gry w piłkę i puszczania balonów; wkrótce i to zarzucił. Jeździł tylko na spacer i chodził pieszo, i to tak prędko, że przy końcu drogi powrotnej biegł w podskokach, okryty grubą opończą lub zarzutką. Dla rozrywki nieraz łowił ryby wędką. To znów grywał z małymi chłopcami w kości, w kamyki znaczone lub orzechy, ściągając zewsząd ładnych i szczebiotliwych chłopców, zwłaszcza Maurów i Syryjczyków. Natomiast do karłów, ułomnych i wszelkich podobnych kalek odczuwał obrzydzenie, uważając ich za złośliwy wybryk natury i unikając jako złej wróżby”. W tłumaczeniu J. Niemirska-Pliszczyńska poszła za poprawką postulowaną przez Filipa Beroalda, który „sestertio” proponował zamienić na „sesticula”. Inne możliwe rozumienie, przedstawione przez Marka Antoniusza Sabelicusa, odnosi „sestertio”, pojmowane etymologicznie, jako dwa i pół, do podskoków Augusta; Caii Svetonii Tranquilli duodecim Caesares cvm Philippi Beroaldi Bononiensis, Marcique item Antonii Sabellici Commentariis \& Bapt. Aegnatii, aliorumque doctorum virorum annotationibus, Lvgdvni 1548, s. 246. I. Gibalini, De vniversa rerum hvmanarvm negotiatione, Lvgdvni 1643, s. 411, uważał, że „sestertio" trzeba poprawić na „segestrio”.

${ }^{38}$ Mistrza Wincentego zwanego Kadlubkiem kronika, ks. 2, rozdz. 12, s. 42; pol. thum. za: Mistrz Wincenty (tzw. Kadłubek), Kronika polska, tłum. B. Kürbis, Wrocław-Warszawa-Kraków 1992, s. 57-58: „Tam ustanowił królem któregoś swojego krewnego, gdy sam król Rusinów nie w bitwie został pokonany, lecz jedynie przez tchórzostwo. Gdy bowiem doniesiono, że zagraża mu Bolesław - a był [wtedy] żywo zajęty błahym łowieniem ryb - porzucił wędkę wraz z królestwem, mówiąc: Schwytał nas na wędkę ten, który sumów łowić nie umie. Ledwo to powiedziawszy, trzęsąc się ze strachu, do ucieczki się rzucił, raczej w ucieczce bezpieczeństwa szukając, niż w starciu bitewnym szczęścia”. 
roli błahej rozrywki. Kronikarz zestawił utratę wędki, przedmiotu bez wartości, którym król Rusinów z zapałem się zabawiał, ze zgubą królestwa, rzeczy najbardziej wartościowej, ale niebronionej przez ruskiego władcę. Autorskim wkładem Kadłubka do opowieści jest wypowiedź Rusina. Wyrasta ona z Gallowego „Bolezlauus huic arti non studuit” (czyli sztuki wędkowania), ale paradoksalnie ten, kto nie umiał łowić, złowił jednak - w sensie metaforycznym - przeciwnika na wędkę. Kadłubek odwołał się w tym miejscu, jak sądzę, do biblijnego znaczenia wędkowania, symbolizującego śmiertelne zagro-

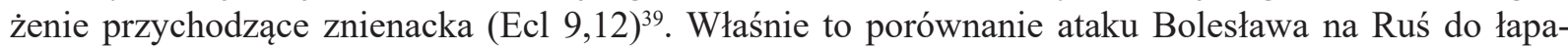
nia choćby i grubej ryby na wędkę najmocniej pokazuje, że kronikarz zupełnie nie rozumiał motywu występującego w tekście Galla.

Skąd jednak mistrz Wincenty wziął sumy (,siluri”)? ${ }^{40}$ Być może inspiracji dostarczył Hexaemeron św. Ambrożego. Kadłubek znał i zacytował trzykrotnie inne dzieło biskupa Mediolanu, De officiis ministrorum $^{41}$. Ponadto przywołał imię Ambrożego, przytaczając jego sentencję za Decretum Gratiani ${ }^{42}$. W Hexaemeronie do sumów zostali porównani ludzie możni i bogaci, którzy w poczuciu bezkarności gnębią biedaków. Tak samo sum pożera mniejsze ryby, przekonany, że jest dostatecznie silny, by wyrwać się z wszelkich zasadzek. „Hamum cave, cave retia” - ostrzegał Ambroży i przepowiadał sumowi, że zostanie złowiony ${ }^{43}$. Mistrz Wincenty udatnie operował dosłownym i przenośnym znaczeniem wędki. Bolesław, który nie umiał łowić prawdziwych sumów, „złapał na hak” króla Rusinów, stając się tym samym narzędziem wyższej sprawiedliwości, karzącej najmożniejszych nawet i najbogatszych.

Jan Długosz w swojej wersji opowiadania wprowadził daleko idące zmiany. „Postquam autem duci Russie Jaroslao, qui tunc voluptati et solaciis deditus, hamo pisces in fluvio Dnyepr, quorum fluvius ipse magnam edit abundanciam, piscaretur, adventus Boleslai Polonorum regis citus et velox denunciatus fuisset, tunc quidem subito pavore perculsus, hamo quem manu gestaverat in terram proiecto: Nichil - inquit - hoc hamo hactenus opus est, neque, ut pisces comprehendamus, sed qualiter hosti occurramus, curandum, ne hostis infesti et potentis, effusionem sanguinis nostri sicientis, hamo involvamur"44. Długosz znał Powieść minionych lat i jako pierwszy uzgodnił jej przekaz z Gallowym opowiadaniem o wyprawie kijowskiej. Przeciwnik Bolesława Chrobrego przestał być tchórzliwym i anonimowym królem Rusinów. Został utożsamiony z powieściowym Jarosławem Mądrym. Strach, który kniaź początkowo poczuł na wieść o polskim najeździe, szybko przeminął i Jarosław, ze wzgardą cisnąwszy wędkę, postanowił podjąć walkę z Bolesławem. Taka zmiana charakterystyki ruskiego władcy wpłynęła na symbolikę wędki. Wędkowanie jest u Długosza przyjemną rozrywką ${ }^{45}$, dodatkowo uzasadnioną szczególną obfitością ryb w Dnieprze. W Rocznikach pojawił się także - za Kadłubkiem - metaforyczny sens wędki, ale zabrakło najważniejszego elementu, konstytuującego Gallową narrację, czyli opozycji

${ }^{39}$ Cytat z Eklezjasty jest obrotowy. Równie dobrze to szatan może łowić dusze ludzkie na wędkę, za pomocą przynęty pokus; np. Dante Alighieri, La Divina Commedia, oprac. A.M. Chiavacci Leonardi, Milano 2011, Purgatorio, canto 14, w. 145-147, s. 431: „Ma voi prendete l'esca, sì che l'amo / de l'antico avversaro a sé vi tira; / e però poco val freno o richiamo”.

${ }^{40}$ Inaczej rozumiał słowo „silurus” Jan z Dąbrówki; Komentarz do Kroniki polskiej Mistrza Wincentego zwanego Kadłubkiem, wyd. M. Zwiercan, A.Z. Kozłowska, M. Rzepiela, w: MPH s.n., t. 14, Kraków 2008, s. 75: „'silurus', -ri, est parvus et minutus piscis a sileo dictus".

${ }^{41}$ B. Kürbis, Wstęp, w: Mistrz Wincenty (tzw. Kadłubek), Kronika polska, s. XCVII.

${ }^{42}$ Mistrza Wincentego zwanego Kadlubkiem kronika, ks. 3, rozdz. 8, s. 93: „Ambrosiane non immemor sententie: arma episcopi lacrime sunt et orationes". O. Balzer, Studyum o Kadłubku, t. 1, Pisma pośmiertne Oswalda Balzera, t. 1, Lwów 1934, s. 165.

${ }^{43}$ Św. Ambroży, Hexaemeron, tłum. o. W. Szołdrski, wstęp o. A. Bogucki OP, oprac. ks. W. Myszor, Warszawa 1969, ks. 5 (dzień piąty), rozdz. 5, 14, s. 146-147.

44 Ioannis Dlugossii Annales seu Cronicae incliti Regni Poloniae, ks. 1-2, wyd. J. Dąbrowski i in., Varsavia 1964, pod 1008 r., s. 259-260; pol. tłum. za: Jana Długosza Roczniki czyli Kroniki sławnego Królestwa Polskiego, ks. 1-2, thum. S. Gawęda, Z. Jabłoński, A. Jochelson, J. Radziszewska, K. Stachowska, A. Strzelecka, tłum. przejrzał M. Plezia, Warszawa 1962, s. 333: „Kiedy doniesiono księciu Rusi, Jarosławowi, o tak nagłym nadejściu Bolesława, króla polskiego, [Jarosław] oddany rozrywkom i uciechom wówczas właśnie łowił ryby wędką w rzece Dnieprze, którego wody zawierają wielką ich obfitość. Przerażony nieoczekiwaną wieścią, rzuciwszy wędkę, którą miał w ręku, rzekł: Nie o wędce ani o łowieniu ryb teraz myśleć, lecz jak oprzeć się srogiemu, potężnemu i krwi naszej chciwemu nieprzyjacielowi, iżby nas samych nie schwytał na wędkę".

${ }^{45}$ Por. R.C. Hoffmann, Fishing for Sport in Medieval Europe. New Evidence, „Speculum”, 60, 1985, nr 4, s. 877-902. 
wędkarstwa i sztuki wojennej. Łapanie ryb na wędkę nie pozbawia Jarosława zdolności militarnych ${ }^{46}$. Średniowieczna tradycja interpretacyjna nie pomaga więc objaśnić „fabułki” Galla, ponieważ w wersjach Kadłubka i Długosza wędkowanie zostało zracjonalizowane i odegrało rolę czczej zabawy w niewłaściwym momencie. Natomiast w przypadku pierwowzoru łapanie ryb stanowi zasadniczy rys osobowości króla i pośrednio całego ludu Rusinów.

Czas przejść do kolejnego etapu procedury badawczej, czyli próby znalezienia w dziele Anonima punktów odniesienia dla interesującej mnie kwestii. Potrzebne są do tego jakieś założenia wstępne, ponieważ „fabella de piscatore” to jedyne miejsce w kronice, w którym występuje wędka. Zakładam więc, że z punktu widzenia Galla wędkowanie (podobnie jak chwytanie zwierzyny za pomocą sieci idę tutaj za biblijnym zrównaniem tych narzędzi i czynności) jest rodzajem polowania, wymagającym posłużenia się sztuką, czy też techniką, dającą myśliwemu wyraźną przewagę nad osaczonymi zwierzętami. Stosunek kronikarza do tego typu łowów jest bez wątpienia negatywny ${ }^{47}$. W kronice aż cztery razy została zastosowana konstrukcja, w której źle postępujących wojowników porównano do myśliwych polujących na zwierzynę z psami, nagonką i sieciami. Potencjalne ofiary albo dzięki sprytowi uchodzą z zasadzki, albo dzięki męstwu same okazują się pogromcami łowców. Tak zaaranżowane jest opowiadanie o drugim (w kronice Anonima) starciu Bolesława Chrobrego z królem Rusinów. Obaj w tym samym czasie wyruszyli na wyprawę wojenną przeciwko sobie. „Cumque nunciatum esset Ruthenorum regi Bolezlauum ultra iam fluvium transivisse inique sui regni confinio cum exercitu consedisse, existimans rex insulsus se quasi feram in retibus eum sua multitudine conclusisse, proverbium ei magne superbie capiti suo retorquendum dicitur mandavisse: Noverit se Bolezlauus tamquam suem in volutabro canibus meis et venatoribus circumclusum" ${ }^{\prime 4}$. Polski władca uświadomił wrogowi, że porównanie do dzika będzie miało śmiertelnie groźne konsekwencje dla miotającego obelgę. Bolesław zapowiedział, że jako „sus in volutabro” zbroczy kopyta swoich koni we krwi łowców i psów, czyli wojowników króla Rusinów, a jako „ferus singularis” pożre ruskie miasta ${ }^{49}$. Bitwa, do której doszło po pewnych perypetiach, przyniosła Polakom wspaniałe zwycięstwo.

Odwołanie się do metaforyki łowieckiej pozwoliło Anonimowi uwypuklić negatywną cechę króla Rusinów, wprost wskazaną na początku opowiadania, czyli pychę. Przeciwnik Chrobrego był pewien zwycięstwa zanim doszło do bitwy. Marek Cetwiński zauważył, że porównanie do określonego typu łowów - z sieciami, psami i łowczymi - sugeruje również inne mankamenty. Ruski władca chciał się wyręczyć swoimi ludźmi, którzy zastawili zasadzkęe . Taki sam wydźwięk mają pozostałe metafory myśliwskie pojawiające się narracjach batalistycznych Anonima. W opowieści o pościgu Bolesława II Szczodrego za Czechami, którzy wyprawili się na Polskę, do łowcy z siecią i psami porównał się polski król, gdy posłał do przeciwników, wyzywając ich do walki. Wcześniej jednak Polacy znienacka obeszli pozycje Czechów i zamknęli im drogę odwrotu, chociaż wrogowie obozowali na równinie, gdzie można było rozegrać bitwę ${ }^{51}$. Epizod ten, podobnie jak prawie wszystkie pozostałe Gallowe opowiadania o Bolesławie II, pokazuje ambiwalencję tego króla. Wprawdzie ścigał wrogów - nawet zbyt gorliwie,

${ }^{46}$ M. Derwich i M. Cetwiński podobne zjawisko odchodzenia od Gallowej symboliki wędki dostrzegli w legendzie herbowej Chrynickich, zapisanej w Gnieździe cnoty Bartosza Paprockiego. Protoplasta rodu stał na straży obozu wojsk polskich i jednocześnie łowił ryby. W jednej ręce trzymał wędkę, a w drugiej konia za wodze. Kiedy znienacka pojawili się Tatarzy, podjął z nimi skuteczną walkę; M. Derwich, M. Cetwiński, Herby, legendy, dawne mity, Wrocław 1987, s. 140-141.

${ }^{47}$ M. Cetwiński, ,Rex insulsus” i ,parasitis exercitus”, czyli pycha Rusina ukarana (Gall, I, 10; Kadtubek, II, 12), w: Europa Środkowo-Wschodnia. Ideologia, historia a społeczeństwo. Księga poświęcona pamięci profesora Wojciecha Peltza, red. J. Dudek, D. Janiszewska, U. Świderska-Włodarczyk, Zielona Góra 2005, s. 327.

${ }^{48}$ Gall Anonim, ks. 1, rozdz. 10, s. 28; pol. tłum., nieco przeze mnie zmodyfikowane (modyfikacje zaznaczam pogrubieniem) za: Grodecki/Plezia, s. 29: „A skoro doniesiono królowi Rusinów, że Bolesław już przeszedł na drugi brzeg rzeki i wraz ze swym wojskiem wkroczył w granice jego królestwa, mdły król przypuszczając, że go osaczył swymi masami [wojska] jak dzikiego zwierza w sieci, przesłał mu podobno słowa [pełne] wielkiej pychy, które spaść miały na jego własną głowę: Niechaj wie Bolesław, że jak dzik w kałuży jest osaczony przez moje psy i łowców".

49 Gall Anonim, ks. 1, rozdz. 10, s. 28.

${ }^{50}$ M. Cetwiński, ,, Rex insulsus” $i$,,parasitis exercitus”, s. 326.

${ }^{51}$ Gall Anonim, ks. 1, rozdz. 24, s. 49. 
bo za bardzo zmęczył swoje wojsko - ale ostatecznie, zamiast bić się z nimi po królewsku, zaszedł ich od tyłu i zastawił pułapkę, co podkreśla porównanie do myśliwego z siecią i psami. Dlatego w finale tej historii Bolesław II dostał gorzką nauczkę. Czeski książę bardzo zręcznie odpowiedział polskiemu królowi i udając pokorę, uśpił jego czujność. Pod osłoną nocy Czesi wymknęli się z zasadzki. Bolesław II był bardzo zły na siebie, że tak mu uciekli i tylko niektórych dogonił i zabił ${ }^{52}$.

Kolejny przypadek deprecjonującego porównania do polowania pojawił się w opowieści o wyprawie polskiego oddziału wysłanego przez Bolesława III na Morawy w celu ich spustoszenia. Napastnicy uderzyli w Wielkim Tygodniu, co spotkało się ze zdecydowanym potępieniem Anonima. Tym też kronikarz tłumaczył śmiertelne zagrożenie, w które Polacy wpadli, gdy książę Świętopełk zaatakował wycofujących się grabieżców i o mały włos ich nie rozgromił. Władca Moraw został przy tej okazji porównany do dzika zabijającego psy myśliwskie, próbujące go osaczyć i siejącego zniszczenie, aż do nadejścia łowczego $\mathrm{z}$ nową sforą ${ }^{53}$. Jeszcze raz Gall posłużył się metaforą łowiecką w opowiadaniu o wojnie domowej między Zbigniewem a Krzywoustym. Bolesław III, otoczony przez trzy wrogie wojska: brata, Czechów i Pomorzan, porównany został do lwa, lub dzika, pobudzonego do ataku ujadaniem psów i trąbieniem myśliwych. Nieustraszony książę rozważał, który z nieprzyjacielskich oddziałów powinien zaatakować najpierw. Natomiast wrogowie, mimo przewagi, bali się uderzyć na Bolesława ${ }^{54}$.

Zestawiając przykłady użycia metafor łowieckich z anegdotą o wędkującym królu Rusinów, trzeba oczywiście pamiętać, że ruski władca łowił ryby zupełnie dosłownie. Metaforyczny sens łapania ryb na haczyk wprowadził do swojej wersji tej opowieści dopiero Wincenty Kadłubek. Zestawienie pozwala jednak zauważyć, że w kronice Galla Anonima kilkakrotnie powtórzone zostało przekonanie o niebohaterskim charakterze chwytania zwierząt jakimkolwiek podstępem czy też dzięki narzędziom, pomocnikom i sztuczkom. Jak spostrzegł M. Cetwiński, hierarchizacja różnych rodzajów polowania - tym razem potraktowanych zupełnie dosłownie - została dokonana w opowiadaniach o młodzieńczych czynach Krzywoustego ${ }^{55}$. Gall stwierdził najpierw: „Interim ne sit alicui aliquatenus admirandum, si quid scripserimus de Bolezlaui puericia memorandum. Non enim, sicut assolet plerumque lascivia puerilis, ludos inanes sectabatur, sed imitari strenuos actus ac militares, in quantum puer poterat, nitebatur. Et quamvis sit puerorum nobilium in canibus et in volucribus delectari, plus tamen solebat Bolezlauus adhuc puerulus in milicia gratulari" ${ }^{56}$. Kronikarz uważał więc polowanie z psami i drapieżnymi ptakami - bo do tego zapewne sprowadza się „upodobanie w psach i ptakach” - za zwyczajną rozrywkę szlachetnych chłopców. Jednak w zestawieniu z czynami wojennymi tego typu łowy są zajęciem próżnym i nieważnym. Wyjątkowy heros od kołyski rwie się na wojnę. Mimo to nieco dalej Anonim przedstawił także dokonania łowieckie dorastającego Krzywoustego. Pewnego razu, w trakcie posiłku spożywanego w lesie, nieopodal „Marsowego chłopca” przeszedł ogromny dzik. Książę chwycił włócznię i zupełnie sam, bez psa, ruszył w pościg za odyńcem. Gdy zamierzył się na zwierzę, jakiś człowiek złapał drzewce jego broni. Bolesław musiał stoczyć podwójny pojedynek. Zdołał wyrwać włócznię z rąk intruza i zabił dzika ${ }^{57}$.

52 Tamże, s. 49-50.

53 Tamże, ks. 2, rozdz. 25, s. 92.

${ }_{54}$ Tamże, rozdz. 37, s. 107.

${ }_{55}$ M. Cetwiński, ,,Rex insulsus” $i$,,parasitis exercitus”, s. 326.

${ }^{56}$ Gall Anonim, ks. 2, rozdz. 9, s. 76; pol. tłum., nieco przeze mnie zmodyfikowane (modyfikacje zaznaczam pogrubieniem) za: Grodecki/Plezia, s. 75: „Tymczasem niech się nikomu nie wyda w żadnym stopniu dziwnym, jeśli zapiszemy coś godnego pamięci o chłopięcym wieku Bolesława. Nie uganiał się on bowiem za czczymi zabawami, jak to zwykła [czynić] częstokroć swawola chłopięca, lecz starał się naśladować dzielne czyny wojenne, o ile mógł to w tym wieku. I aczkolwiek jest zwyczajem chłopców szlachetnych zabawiać się psami i ptakami, to Bolesław, jeszcze jako chłopiec, więcej cieszył się walką zbrojną".

${ }^{57}$ Gall Anonim, ks. 2, rozdz. 11, s. 77; J. Banaszkiewicz, Młodzieńcze gesta Bolesława Krzywoustego, czyli jak zostaje się prawdziwym rycerzem $i$ władca, w: tenże, Takie sobie średniowieczne bajeczki, wprow. M. Tomaszek, Kraków 2012, s. 517-525; A. Gronowska, Fabuly rycerskie w „, Gesta ducum sive principum Polonorum” Galla Anonima na tle wybranych przykładów piśmiennictwa średniowiecznego (do końca XIII w.), Warszawa 2010, praca doktorska obroniona na Wydziale Polonistyki UW, s. 85. 
Gall opowiedział jeszcze jedną, podobną historię. Młody Krzywousty jechał z towarzyszami przez las i zobaczył wielkiego niedźwiedzia, zabawiającego się z niedźwiedzicą. Samotnie podjechał konno do zwierząt. Gdy niedźwiedź zaatakował księcia, ten przebił go oszczepem ${ }^{58}$. „Młodzieńcze gesta” Bolesława III zawierają analogiczne wywyższenie wojny ponad polowanie, co „fabella de rege piscatore" (o ile potraktować wędkowanie jako rodzaj łowów). Z czynami militarnymi mogą się ewentualnie równać samotne zmagania z grubym zwierzem. Wszelkie metody osaczania zwierzyny jakimś sposobem - przy pomocy łowców, psów lub drapieżnych ptaków albo z użyciem sieci - są dalece mniej bohaterskie od pojedynku z dużą i niebezpieczną bestią. Nie znaczy to jednak, że szlachetnemu człowiekowi uwłaczało polowanie z nagonką i wszelkiego rodzaju pomocnikami. Na pewno nie pasowało ono natomiast do wizerunku wielkiego, wyjątkowego bohatera, pragnącego zostać wybitnym władcą. Również w tym miejscu kroniki Anonima daje o sobie znać ekskluzywizm ideału wojowniczego monarchy. Może więc wędkowanie hańbiło króla Rusinów właśnie dlatego, że powinien on być wspaniałym władcą, wspanialszym i waleczniejszym od Bolesława Chrobrego, skoro odmówił mu ręki siostry.

Przyszedł czas na najważniejszą część wywodu, czyli porównanie Gallowej opowiastki z narracjami nieznanymi Anonimowi i niezależnymi od jego kroniki. Kryterium doboru jest podobieństwo. Jak pokazał przykład anegdoty o carze Aleksandrze III, przy dobieraniu materiału porównawczego należy skoncentrować się na rozbrajającym w sensie wojskowym i antybohaterskim aspekcie wędkowania. Oprócz uwłaczającego władcom (lub herosom) wędkowania interesuje mnie także powiązanie wędki z cechami przypisanymi królowi Rusinów: prostotą i bogactwem. Zacznę od sprawdzenia tropu wskazanego przez E. Skibińskiego, czyli Króla-Rybaka. Postać ta pojawiła się po raz pierwszy w Le roman de Perceval ou le conte du Graal, ostatnim utworze Chrétiena de Troyes, napisanym na początku lat 80 . XII w. ${ }^{59}$ Perceval, tytułowy bohater powieści, był chłopcem z możnego rodu. Matka chowała go we dworze w Przeklętym Lesie i starała się ukryć przed nim fakt istnienia rycerstwa. W rycerskich pojedynkach zginęli bowiem dwaj starsi bracia Percevala. Na wieść o ich śmierci z żalu zmarł też jego ojciec. Pewnego razu, podczas polowania, chłopak zobaczył przypadkiem jednego z rycerzy króla Artura. Zachwycony, postanowił udać się na zamek Cardoeil, aby zostać pasowanym przez władcę. W chwili jego odjazdu matka Percevala padła zemdlona i rychło umarła, o czym junak zmierzający do siedziby Artura nie wiedział. Po licznych przygodach: zabiciu Czerwonego Rycerza (Chevalier Vermeil), odebraniu rycerskich nauk od Gornemanta de Gorhaut (który pasował młodzieńca na rycerza), po pokonaniu wrogów pięknej Blancheflor, siostrzenicy Gornemanta i zdobyciu jej serca, Perceval postanowił wrócić do domu. Po drodze, w nieznanej sobie okolicy, dotarł wieczorem nad ogromną rzekę. Kiedy bezradny zatrzymał rumaka na skale nad brzegiem, zobaczył dwóch ludzi w łodzi. „Et cil qui fu devant peschoit / A la ligne et si aeschoit / Son ameçon d'un poissonet / Petit greignor d'un vaironnet" 60 .

Perceval zapytał wędkującego o najbliższy most lub bród. Użył przy tym tytułu seignor, czyli potraktował go jak możnego pana ${ }^{61}$. Rybak odpowiedział, że nie ma żadnej możliwości przekroczenia rzeki wraz z koniem i zaprosił Percevala do swojej pobliskiej siedziby na nocleg. Młody rycerz wyruszył niezwłocznie, ale zrazu nie dostrzegł żadnego budynku. Zdążył już nawet przekląć Rybaka za jego kłamstwo i dopiero wtedy ujrzał okazały zamek. Nastrój bohatera odmienił się natychmiast. Perceval pochwalił Rybaka i nie nazywał go już oszustem (tricheor), przeniewiercą (desloial) i kłamcą

58 Gall Anonim, ks. 2, rozdz. 12, s. 77.

${ }^{59}$ K. Busby, Chrétien de Troyes, „Perceval” (,Le Conte du Graal”), Critical Guides to French Texts, t. 98, London 1993 , s. 9.

${ }^{60}$ Chrétien de Troyes, Le roman de Perceval ou le conte du Graal, wyd. K. Busby, Tübingen 1993, w. 3007-3010, s. 127-128: „I ten, który był z przodu, łowił ryby na wędkę i założył na swój haczyk jako przynętę rybę niewiele większą od płotki” [thum. P.Ż.]; por. pol. tłum.: Chrétien de Troyes, Percewal z Walii czyli opowieść o Gralu, thum. A. Tatarkiewicz, w: Arcydzieła francuskiego średniowiecza, wybór M. Żurowski, oprac. Z. Czerny, Warszawa 1968, s. 525.

${ }^{61}$ Chrétien de Troyes, Le roman de Perceval, w. 3014, s. 128; B.N. Sargent-Baur, „Avis li fu”. Vision and Cognition in the „Conte du Graal”, w: Continuations. Essays on Medieval French Literature and Language in Honour of John L. Grigsby, red. N.J. Lacy, G. Torrini-Roblin, Birmingham (Ala.) 1989, s. 139. 
(mençoignier) ${ }^{62}$. Przybysz został przyjęty bardzo uprzejmie. Rybak dał mu wspaniały miecz, przysłany akurat przez siostrzenicę. W sali biesiadnej okazało się, że gospodarz jest inwalidą i nie może wstać, by uroczyście przywitać gościa. W trakcie wieczornej uczty ludzie pana zamku trzy razy przeszli przez salę, niosąc gdzieś niezwykłe i tajemnicze przedmioty: krwawiącą włócznię, złote i bogato zdobione świeczniki na 10 świec, złotego Graala, wysadzanego kamieniami szlachetnymi o ogromnej wartości, oraz srebrną tacę. Perceval bardzo chciał poznać tożsamość swojego dobroczyńcy i dowiedzieć się czegoś o zaprezentowanych skarbach, ale milczał w obawie, że jego pytania będą świadczyć o braku ogłady. Po nadzwyczajnie sutej kolacji służba wyniosła łoże wraz z gospodarzem. Natomiast Perceval położył się spać w sali biesiadnej.

Gdy rano wstał, zamek był opustoszały. Wyjechał więc i przejeżdżając przez las, napotkał dziewczynę płaczącą nad ciałem poległego rycerza. Wywiązała się rozmowa, podczas której Perceval opowiedział, gdzie spędził noc. Rozmówczyni znała pana zamku. ,- Ha! sire, vos jeüstes donques / Chiez le riche Roi Pescheor. / - Pucele, par le Salveor, / Ne sai s'il est peschierre ou rois, / Mais molt est riches et cortois. / Rien plus dire ne vos en sai, / Fors tant que .ii. homes trovai / Hier soir molt tart en une nef, / Qui aloient najant soëf. / Li .i. des .ii. homes nagoit, / L'autres a l'ameçon peschoit, / Et cil sa maison m'ensaigna / Ersoir, et si me heberga. / Et la pucele dist: - Biax sire, / Rois est il, bien le vos os dire / Mais il fu en une bataille / Navrez et mahaigniez sanz faille, / Si que puis aidier ne se pot, / Qu'il fu ferus d'un gavelot / Parmi les hanches ambesdeus, / S'en est encor si angoisseus / Qu'il ne peut sor cheval monter. / Mais quant il se velt deporter / Ou d'aucun deduit entremetre, / Si se fait en une nef metre / Et va peschant a l'ameçon; / Por che li Rois Peschierre a non. / Et por che ensi se deduit / Qu'il ne porroit autre deduit / Por rien soffrir ne endurer. / Ne puet chacier ne riverer, / Mais il a ses rivereors, / Ses archiers et ses veneors, / Qui vont en ses forés berser. / Et por che li plaist converser / En cest repaire ci alués, / Qu'en tot le mont a oés son oés / Ne puet trover meillor repaire, / Et si a fait tel maison faire / Come il convient a riche roi" ${ }^{\prime 3}$.

W dalszym ciągu rozmowy Perceval przyznał się, że nie zapytał gospodarza ani o krwawiącą włócznię, ani o Graala. Dziewczyna zaczęła czynić mu wyrzuty i nazwała nieszczęsnym. Pytanie uleczyłoby bowiem Króla-Rybaka i mógłby on dalej władać swoim krajem. Kolejne szczegóły na ten temat pojawiły się w powieści dużo później. Perceval pokonał kilku słynnych rycerzy i w pełni chwały ponownie odwiedził dwór króla Artura. Radosną fetę przerwało przybycie szpetnej panny na mule. Przeklęła ona Percevala za jego milczenie podczas wieczerzy u Króla-Rybaka. Według niej przez to wędkujący władca nie tylko stracił szansę na uzdrowienie, ale i straci swoje królestwo, które zostanie spustoszone, przy czym wielu ludzi zginie ${ }^{64}$. Pensum informacji o Królu-Rybaku dopełnił pustelnik, do którego tytułowy bohater powieści trafił po pięciu latach tułaczki. Świątobliwy mąż okazał się zresztą stryjem niepełnosprawnego monarchy i wujem Percevala. Objaśnił on, że w Graalu słudzy noszą Hostię staremu królowi, ojcu Rybaka, który od dwunastu lat nie przyjmuje innych pokarmów ${ }^{65}$.

${ }^{62}$ Chrétien de Troyes, Le roman de Perceval, w. 3035-3064, s. 129-130; Chrétien de Troyes, Percewal z Walii, s. 526.

${ }^{63}$ Chrétien de Troyes, Le roman de Perceval, w. 3493-3533, s. 149-151: „- Ha, panie, gościłeś właśnie u bogatego Króla-Rybaka. - Dziewczyno, na Zbawiciela, nie wiem czy on jest rybakiem, czy królem, ale bardzo jest bogaty i dworny. Nie powiem nic, czego wy nie wiecie, oprócz tego, że bardzo późnym wieczorem znalazłem tutaj dwóch ludzi w jednej łodzi, którzy płynęli spokojnie. Jeden z nich kierował łodzią, drugi łowił ryby na wędkę i ten wskazał mi swój dom w ten wieczór, i ugościł mnie. I dziewczyna powiedziała: - Piękny panie, on jest królem. Dobrze wasze usta rzekły, ale w pewnej bitwie został ranny i okaleczony tak poważnie, że nie można mu już pomóc. Został trafiony włócznią pomiędzy biodra. Z tego powodu jest tak niesprawny, że nie może wsiadać na konia. Kiedy chce wyjść lub czymś się zająć, niosą go do łódki i łowi ryby na wędkę. Dlatego nazywa się Królem-Rybakiem. I takiej rozrywki zażywa, ponieważ żadnej innej nie może. Ponieważ niczego nie zniesie, ani nie wytrzyma, nie może polować. Ale ma swoich łowców, swoich łuczników i swoich myśliwych, którzy chodzą polować w jego lasach. I dlatego on lubi mieszkać w tej kryjówce, tutaj położonej, która na całym świecie jest dla niego najlepsza. Nie mógł znaleźć lepszej kryjówki i dlatego przerobił ten dom na taki, który przystoi bogatemu królowi" [tłum. P.Ż.]; por. Chrétien de Troyes, Percewal z Walii, s. 532-533.

${ }^{64}$ Chrétien de Troyes, Le roman de Perceval, w. 4646-4683, s. 197-199; Chrétien de Troyes, Percewal z Walii, s. 551.

${ }^{65}$ Chrétien de Troyes, Le roman de Perceval, w. 6413-6433, s. 271-272; Chrétien de Troyes, Percewal z Walii, s. 578-579. 
Różnice między Królem-Rybakiem a królem Rusinów są w gruncie rzeczy niewielkie ${ }^{66}$. Sprowadzają się do tego, że ten pierwszy był weteranem wojennym, który w bitwie odniósł poważną ranę, odzierającą go z godności ${ }^{67}$, natomiast drugi zaprezentowany został jako niewojowniczy tchórz. Gdy Gallowy król Rusinów usiłował prowadzić wojnę, czynił to w sposób niegodny bohatera. Poza tym z Le roman de Perceval dowiadujemy się o dworności Króla-Rybaka. Nic nie wskazuje, aby Gall przypisywał analogiczną cechę władcy ruskiemu. Mimo tych odmienności kontekst królewskiego wędkowania u Chrétiena de Troyes jest taki sam jak u Anonima. Król-Rybak łowił ryby wędką dla rozrywki, ponieważ nie mógł dosiadać konia i polować. Kalectwo doprowadziło go do całkowitej dysfunkcji rycerskiej. Jej czytelnym symbolem jest właśnie wędka i łowienie ryb ${ }^{68}$, od którego - co znaczące - pochodzi przezwisko postaci. Pod znakiem zapytania stoi też królewskość wędkującego. Perceval zwrócił się wprawdzie do niego, używając tytułu seignor, ale poinformowany przez dziewczynę o jego monarszej godności odrzekł: „nie wiem, czy on jest rybakiem, czy królem” (Ne sai s'il est peschierre ou rois) ${ }^{69}$. Sądząc z wypowiedzi junaka, określenie Roi Pescheor / Rois Peschierre wydaje się oksymoronem. Ktoś, kto łapie ryby na wędkę, najwyraźniej nie może być wzięty za króla. Dlatego Chrétien, tak samo jak Anonim, każe wędkować takiemu władcy, który nie jest w stanie obronić swojego władztwa i wedle przepowiedni szpetnej dziewczyny na mule utraci je.

Król-Rybak i król Rusinów mają także inne wspólne cechy. Obaj są bogaci. O dostatkach postaci z powieści Chrétiena dobitnie świadczy określenie użyte przez dziewczynę: „le riche Roi Pescheor”, w którym przymiotnik „riche” brzmi jak przydomek. W Le roman de Perceval mocno podkreślona została kosztowność tajemniczych przedmiotów znajdujących w siedzibie Króla-Rybaka oraz wystawność kolacji podanej gościowi. Na bogactwo swojego gospodarza zwrócił uwagę Perceval w rozmowie z dziewczyną. Dodać do tego należy jeszcze pochwały pod adresem domu królewskiego, wzniesionego „Come il convient a riche roi”70. Król Rusinów sam wspomniał (u Anonima) o swoich utraconych bogactwach, kiedy ogłosił zwycięstwo Bolesława Chrobrego. W dalszym ciągu opowiadania kronikarz dodał: „Igitur rex Bolezlauus urbe ditissima regnoque Ruthenorum potentissimo decem mensibus potitus, inde pecuniam in Poloniam transmittendo nunquam extitit otiosus" "71. Jeszcze jedna cecha Króla-Rybaka - niemożność samodzielnego polowania, powodująca konieczność wysługiwania się łowcami - koresponduje z drugą opowieścią o królu Rusinów u Galla. Ruski władca - przypominam - zapowiedział przed bitwą, że jego wojsko rozprawi się z Bolesławem Chrobrym i Polakami, tak jak łowcy

${ }^{66}$ Z punktu widzenia porównania króla Rusinów do Króla-Rybaka i określenia symboliki wędki bezużyteczne okazują się poszukiwania mitologicznego, chrystologicznego czy literackiego wzorca postaci z Percevala, które były bardzo żywotnym kierunkiem badań. Literatura na ten temat jest ogromna, podaję więcej niż skromny wybór: A.H. Krappe, The Fisher King, „The Modern Language Review”, 39, 1944, nr 1, s. 18-23; W.A. Nitze, How did the Fisher King get his Name?, w: Mediaeval Studies in Honor of J.D.M. Ford, wyd. U.T. Holmes, A.J. Denomy, Cambridge 1948, s. 177-182; H. i R. Kahane, Proto-Perceval and Proto-Parzival, „Zeitschrift für romanische Philologie”, 79, 1963, nr 3-4, s. 337; A. Stone, Bran, Odin, and the Fisher King. Norse Tradition and the Grail Legends, „Foklore”, 100, 1989, nr 1, s. 25-38; L. Mathey-Maille, Le Roi Pêcheur dans quelques récits médiévaux, <https://gric.univ-lehavre.fr/IMG/pdf/mathey-2.pdf> [dostęp 10.03.2016], s. 5. Mało przydatny dla mnie jest wykład symboliki wędki Króla-Rybaka w: J. Berchtold, L'échiquier absent. A propos d'une disparition signifiante dans le „Conte du Graal” de Chrétien de Troyes, w: Désordres du jeu - poétiques ludiques. Études d'histoire et de littérature, red. J. Berchtold, Ch. Lucken, S. Schoettke, Genève 1994, s. 113-124. J. Berchtold zupełnie nie wziął pod uwagę nierycerskiego aspektu wędki w powieści Chrétiena.

${ }^{67}$ W. Sayers, An Archaic Tale-Type Determinant of Chrétien's Fisher King and Grail, „Arthuriana”, 22, 2012, nr 2, s. 91.

${ }^{68}$ R.C. Hoffmann, Fishing for Sport, s. 888-889, brał motyw wędkowania w Percevalu za jedno z wczesnych świadectw traktowania łowienia ryb na wędkę jako sportu i zabawy. Nie zauważył, że Chrétien de Troyes uważał wędkowanie za rozrywkę najpodlejszego rodzaju. Król-Rybak oddawał się jej tylko dlatego, że nie mógł już pełnić roli rycerza i władcy.

69 J. Marx, La légende arthurienne et le Graal, Genève 1996 (reprint wyd.: Paris 1952), s. 193; L. Mathey-Maille, Le Roi Pêcheur, s. 2. Tak samo słowa Chrétiena przełożył D. Staines: „I don’t know if he is a fisherman or a king”; The Complete Romances of Chrétien de Troyes, thum. D. Staines, Bloomington-Indianapolis 1993, s. 382.

${ }^{70} \mathrm{O}$ zamku Króla-Rybaka zob. J. Kowalski, Rymowane zamki. Tematy architektoniczne w literaturze starofrancuskiej drugiej polowy XII wieku, Warszawa 2001, s. 285-293.

${ }^{71}$ Gall Anonim, ks. 1, rozdz. 7, s. 23; pol. tłum. za: Grodecki/Plezia, s. 24: „Król Bolesław więc, zawładnąwszy przebogatym miastem [czyli Kijowem - P.Ż.] i potężnym królestwem ruskim, przez przeciąg dziesięciu miesięcy niestrudzenie przesyłał stamtąd pieniądze do Polski”. 
i psy rozprawiają się z osaczonym i skrępowanym siecią dzikiem. Z różnych powodów i w różnych kontekstach obie postacie odżegnują się od osobistego udziału w łowach bądź bitwie porównanej do finału polowania, ale za każdym razem jest to niebohaterskie i kompromitujące z punktu widzenia ideału wojownika, rycerza czy króla.

Warto wspomnieć o kolejnych aspektach opowiadania o Królu-Rybaku, które mogą okazać się przydatne. Chrétien de Troyes określił miejsce, w które ranny został monarcha. Włócznia trafiła go między biodra („Parmi les hanches ambesdeus”). Jest to niedwuznaczna sugestia, że Król-Rybak stracił nie tylko władzę w nogach, ale i swoją męskość ${ }^{72}$. Ten nieszczęsny, z przymusu nierycerski władca posiadał cudowne przedmioty i świętego ojca, żywiącego się wyłącznie Hostią. Wojskowa, męska indolencja Króla-Rybaka została w Le roman de Perceval wynagrodzona na poziomie sakralnym.

Szczegóły przywodzące na myśl Gallową opowiastkę o królu Rusinów można napotkać w żywocie Marka Antoniusza Plutarcha z Cheronei ${ }^{73}$. Postać imperatora rysuje się w utworze niejednoznacznie. Antoniusz jest przedstawiony jako bardzo dzielny żołnierz i wybitny, charyzmatyczny wódz. Jednocześnie są mu przydane negatywne cechy i zachowania, kojarzone z wojskowym stylem życia: hulanki, rozpusta, pijaństwo, próżność, swobodne szafowanie majątkiem i życiem ludzkim. W przekonaniu Plutarcha najgorszą rzeczą, jaka się Antoniuszowi w życiu przydarzyła, była miłość do Kleopatry. Zniszczyła ona jego przymioty i wzbudziła złe namiętności ${ }^{74}$. Gdy tylko poznał królową Egiptu, porzucił sprawy poważne, a było co porzucać. Plutarch zaznaczył, że w owym czasie Fulwia, żona Antoniusza, broniąc jego interesów, popadła w Italii w konflikt z Oktawianem, a wschodnim prowincjom zagroził najazd Partów. Tymczasem Antoniusz udał się z Kleopatrą do Aleksandrii, gdzie oddał się chłopięcym błazeństwom i niezwykle kosztownym ucztom oraz zabawom ${ }^{75}$. Królowa owładnęła nim całkowicie. Stali się nierozłączni. Kleopatra piła z Antoniuszem i grała z nim w kości. Oboje włóczyli się nocami po mieście w strojach niewolników, zażywając mniej wyrafinowanych rozrywek niż w pałacu i wszczynając awantury. Plutarch stwierdził wreszcie, że wiele można by opowiadać o jego wygłupach godnych młodego chłopca i postanowił dać jeden jeszcze przykład. Pewnego razu Antoniusz w obecności Kleopatry łowił ryby na wędkę, ale bez powodzenia. Kazał więc rybakom skrycie nurkować i zaczepiać na haczyku wcześniej złowione przez nich okazy. Królowa spostrzegła oszustwo, ale nie dała tego po sobie poznać. Pochwaliła kochanka i na wędkowanie zaplanowane na następny dzień zaprosiła wielu przyjaciół. Kiedy na oczach zgromadzonej publiczności Antoniusz zarzucił wędkę, nurek Kleopatry zaczepił mu na haczyku solonego śledzia pontyjskiego. Wyciągnięcie takiej zdobyczy wzbudziło gromki śmiech. Królowa powiedziała wówczas: „Autokratorze, zostaw wędkę nam, faryjskim i kanobijskim królom. Twoim połowem są miasta, królestwa i kontynenty" [tłum. M. Brożek] ${ }^{76}$. W trakcie takich głupich, dziecinnych rozrywek doszły do Antoniusza złe wiadomości. Jego żona i brat Lucjusz przegrali wojnę z Oktawianem i zostali zmuszeni do ucieczki z Italii, a do Syrii wkroczyła armia partyjska ${ }^{77}$.

$\mathrm{Z}$ anegdotą o wędkującym Antoniuszu koresponduje przekonanie Plutarcha, wyrażone dobitnie w Moraliach, że łapanie ryb na haczyk jest zajęciem podłym z kilku powodów. W przeciwieństwie do polowania na grubego lądowego zwierza, które dostarcza okazji do ćwiczenia hartu ducha i ciała,

${ }^{72}$ K.G. Tracy, Representations of Disability. The Medieval Literary Tradition of the Fisher King, w: Disability in the Middle Ages. Reconsiderations and Reverberations, red. J.R. Eyler, Farnham 2010, s. 107.

73 Dziękuję dr Marcie Tycner za wskazanie mi anegdoty o wędkującym Marku Antoniuszu. Za konsultacje dziękuję dr. hab. Aleksandrowi Wolickiemu. Winien jestem wdzięczność także dr. hab. Pawłowi Sawińskiemu.

74 Plutarch, Lives, t. 9: Demetrius and Antony, Pyrrhus and Caius Marius, thum. na ang. B. Perrin, Cambridge (Mass.)-London 1996 (reprint), Antony, s. 190; pol. tłum. za: Plutarch z Cheronei, Żywoty sławnych mężów (z żywotów równoległych), tłum. M. Brożek, Wrocław-Warszawa-Kraków 1997, s. 294.

75 Plutarch, Antony, rozdz. 28, s. 196.

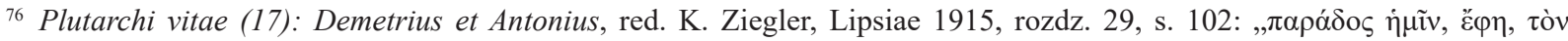

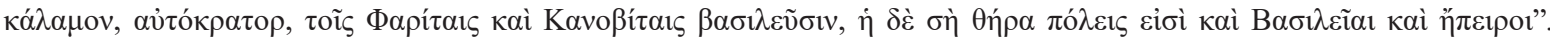

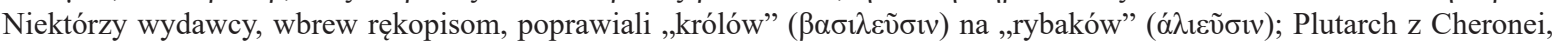
Żywoty sławnych mężów, s. 296.

77 Plutarch, Antony, rozdz. 30, s. 202-204. 
chwytanie ryb jest bezwartościowe. W tym miejscu Plutarch powołał się na autorytet Platona. Mankament wędkowania polega też na tym, że w istocie rzeczy sprowadza się ono do oszukiwania. Ryby nieświadomie wpadają w zasadzkę. Żaden z bogów nie przybrał przydomka „zabójca ryb”, natomiast Apollo nazywał się zabójcą wilków, a Artemida zabójczynią jeleni. W ostatecznym rozrachunku - zdaniem autora Moraliów - lepiej więc kupić rybę na targu, niż ją samemu złowićn ${ }^{78}$.

Trzeba z całą mocą podkreślić, że Antoniusza nie ośmiesza w utworze Plutarcha jedynie wędkowanie, ale próba oszukańczego popisania się przed Kleopatrą udanym połowem. Pozostałe elementy opowiadania dobrze objaśniają Gallowy passus o królu Rusinów. Antoniusz u Plutarcha jest wojskowym par excellence. Gdy zabiera się do łowienia na wędkę, zupełnie mu to nie wychodzi. Najwyraźniej wybitny wódz nie może być dobrym wędkarzem. Po tym epizodzie Plutarch opowiedział o partyjskiej kampanii Antoniusza, w czasie której okazało się, że kompletnie utracił on talenty dowódcze. Przeciwstawienie łowienia ryb na haczyk i wojen zdobywczych najdobitniej zostało wyrażone w wypowiedzi Kleopatry. Padają w niej dwie nazwy ważnych punktów na wybrzeżu egipskim: Faros, wysepki u wejścia do portu w Aleksandrii, na której stała słynna latarnia morska, oraz miasta portowego Kanobos. Wędka wydaje się odpowiednia dla władców takich jak Kleopatra, kobiet dysponujących nieograniczonymi bogactwami i przyjemnościami. Wielki autokrator powinien chwytać nie ryby, a miasta, królestwa i kontynenty. Tym przewrotniejsze jest, że to królowa poucza Antoniusza. Przecież zdaniem biografa właśnie zły wpływ Kleopatry sprawił, że rzymski wódz zabawiał się uwłaczająco błahymi zajęciami. Plutarch, podobnie jak Gall Anonim, wędkowanie uczynił czytelnym symbolem zatraty (bądź braku) umiejętności wojskowych. Dlatego łowienie ryb na wędkę zestawione zostało z atakami wrogów, które miały położyć kres panowaniu Antoniusza, stając się punktem kulminacyjnym Plutarchowego utworu.

Motyw wędki odgrywa istotną rolę w łacińskim poemacie o Walthariusie, spisanym w IX lub X w. w klasztorze Sankt Gallen. W XI w. utwór z niewielkimi zmianami i dopełnieniem został włączony do kroniki klasztoru w Novalesie ${ }^{79}$. Treść poematu jest następująca. Hunowie usadowili się w Panonii i pokonali wielu królów w Europie. Wśród zwyciężonych był władca Franków Gibicho, który oprócz trybutu musiał wysłać na dwór Attyli swojego szlachetnego wojownika Hagana jako zakładnika. Podobnie postąpili inni królowie. Hereryk z Burgundii oddał Hunom swoją córkę Hilgundę, a Alfere z Akwitanii swojego syna Walthariusa. Kiedy zmarł Gibicho, jego następca, Gunther, odmówił płacenia trybutu, a Hagan potajemnie zbiegł z dworu Attyli. Władca Hunów obawiał się, że Waltharius pójdzie w ślady frankijskiego wojownika. Za radą żony postanowił zaaranżować małżeństwo Akwitańczyka z huńską dziewczyną. Waltharius zręcznie odmówił, thumacząc, że obciążony sprawami domowymi, rodzinnymi i gospodarskimi z mniejszym poświęceniem służyłby Attyli. Bohater poematu solennie przysiągł wierność władcy Hunów, którego nazwał przy tej okazji najlepszym ojcem. I jakby na zawołanie jakiś lud zbuntował się przeciwko Attyli. Waltharius stanął na czele wojska huńskiego i odniósł świetne zwycięstwo.

Należy zdecydowanie podkreślić, że wojenne przewagi bohatera poematu przedstawione zostały w sposób właściwy dla wielkich, wspaniałych wodzów i monarchów. Waltharius uszykował wojowników huńskich i zagrzał ich do boju przemową. Gdy oba wojska się starły, sam rzucił się w środek bitwy i siał spustoszenie wśród wrogów ${ }^{80}$. Tym gorzej więc świadczy o nim plan ucieczki, którego mimo obietnic złożonych Attyli - nie zarzucił. Co więcej, namówił Hilgundę, aby uciekła wraz z nim. Okazji miała dostarczyć uroczysta uczta na cześć zwycięzcy. Waltharius poprosił dziewczynę o zabranie cennej broni i kosztownych przedmiotów ze skarbca Attyli, a w dalszym ciągu wypowiedzi nakazał jej: „Insuper a fabris hamos clam posce retortos / Nostra viatica sint pisces simul atque volucres / Ipse ego

78 T.H. Corcoran, Roman Fishermen, „The Classical World”, 56, 1963, nr 4, s. 102; Plutarch, Moralia, thum. na ang. H. Cherniss, W.C. Helmbold, t. 12, Cambridge (Mass.) 1957, 965F-966B, s. 359-365.

${ }^{79}$ G. Labuda, Rozwój zachodnioeuropejskiego eposu o Walterze, w: tenże, Źródła, sagi i legendy do najdawniejszych dziejów Polski, Warszawa 1961, s. 266-276.

${ }^{80}$ Waltharius, wyd. G. Vogt-Spira, Stuttgart 1994, w. 173-214, s. 48-52; Cronaca di Novalesa, wyd. G.C. Alessio, Torino 2006 (reedycja), ks. 2, rozdz. 9, s. 80-82. 
piscator sed et auceps esse coartor"81. Waltharius z bohatera wojennego i triumfatora postanowił przeistoczyć się w oszusta, złodzieja i uciekiniera. Taka zmiana zmusza do podjęcia działań odpowiednich do nowej roli. Łapanie ryb na wędkę i ptaków w pułapki jest zajęciem korespondującym z nowym, antybohaterskim statusem ${ }^{82}$.

W trakcie uczty Hunowie upili się i zasnęli. Waltharius zabrał najlepszego konia ze stajni Attyli. Objuczył go skrzynią z kosztownościami oraz jedzeniem i dał do prowadzenia Hilgundzie. Natomiast sam ubrał się w pancerz „obyczajem olbrzymów”, założył hełm, przypasał miecz i niósł tarczę w ręku. „Femina duxit equum nonnulla talenta gerentem / In manibusque simul virgam tenet ipsa colurnam / In qua piscator hamum transponit in undam / Ut cupiens pastum piscis deglutiat hamum / Namque gravatus erat vir maximus undique telis / Suspectamque habuit cuncto sibi tempore pugnam" "83. Przy okazji przedstawienia początku wędrówki uciekinierów doszło do symbolicznego uporządkowania przedmiotów. Waltharius, spodziewając się huńskiego pościgu (który zresztą nie wyruszył), szedł uzbrojony. Kosztowności i wędkę miała pod swoją pieczą kobieta.

Kwestia łapania ryb i ptaków wróciła w podsumowaniu opowiadania o ucieczce z Panonii na zachód. „Waltharius fugiens ut dixi noctibus ivit / Atque die saltus arbustaque densa requirens / Arte accersitas pariter capit arte volucres / Nunc fallens visco, nunc fisso denique ligno / Ast ubi pervenit, qua flumina curva fluebant / immitens hamum rapuit sub gurgite praedam / Atque famis pestem pepulit tolerando laborem / Namque fugae toto se tempore virginis usu / Continuit vir Waltharius laudabilis heros" Obraz Walthariusa-zbiega mocno kontrastuje z jego wcześniejszą postawą zwycięskiego, bohaterskiego wodza. Wędkowanie i chwytanie ptaków w pułapki zostało zestawione z działaniami potajemnymi: nocną aktywnością oraz ukrywaniem się w gęstwinie w dzień. W tym kontekście określenie „laudabilis heros", którym obdarzył Walthariusa autor, brzmi jak ironia ${ }^{85}$.

Łowienie ryb odegrało istotną rolę $\mathrm{w}$ dalszej części poematu. Po czterdziestu dniach uciekinierzy dotarli nad Ren. Przewoźnik przeprawił ich na drugi brzeg rzeki. Za zapłatę wziął ryby i zaniósł je królewskiemu kucharzowi do Wormacji, stolicy Gunthera. Były to okazy złowione przez Walthariusa wcześniej. Król poznał, że nie pochodzą z kraju Franków i zaczął dopytywać, skąd się wzięły. Przewoźnik opowiedział, kto mu w ten sposób zapłacił za przeprawę. Hagan domyślił się, że to Waltharius i Hilgunda przebyli Ren. Od przewoźnika Gunther dowiedział się także o skarbach. Król uznał, że kosztowności ukradzione przez Walthariusa Attyli muszą pochodzić z trybutu zapłaconego Hunom przez jego poprzednika Gibichona. Za parą zbiegów ruszył więc frankijski pościg z Guntherem i Haganem na czele. Frankowie doścignęli ich w bardzo wąskim wąwozie o szerokości jednego człowieka. W tych sprzyjających warunkach Waltharius zabił po kolei wszystkich jedenastu towarzyszy Gunthera

81 Waltharius, w. 271-273, s. 58: „Ponadto od rzemieślników potajemnie zażądaj wygiętych haczyków. Naszym pożywieniem będą ryby, a także ptaki. Ja sam zmuszony jestem być rybakiem, ale i ptasznikiem” [tłum. P.Ż.]. Te same słowa pojawiają się w wersji zawartej w: Cronaca di Novalesa, ks. 2, rozdz. 9, s. 84.

82 A. Gronowska, Fabuly rycerskie, s. 85-87.

83 Waltharius, w. 341-346, s. 64: „Kobieta prowadziła konia niosącego wielkie bogactwa, zarazem sama w rękach niosła tyczkę leszczynową, którą rybak haczyk przenosi w fale, jak chce, żeby ryba połknęła przynętę na haku; bowiem wielki mąż wyłącznie obciążony był bronią i cały czas spodziewał się walki” [tłum. P.Ż.]; Cronaca di Novalesa, ks. 2, rozdz. 9, s. 88 - w kronice zacytowane są dosłownie trzy pierwsze z przytoczonych przeze mnie wersów, czwarty wers wypadł, a dwa następne są nieco zmienione.

${ }^{84}$ Waltharius, w. 419-427, s. 72: „Waltharius uciekając, jak powiedziałem, szedł nocami, a we dnie szukał lasów i gęstych zarośli. Sztuką przywołane ptaki tak samo sztuką łapał, już to zwodząc jemiołą, już to świstawką z drewna. Aż tam doszedł, gdzie kręte rzeki płyną. Zarzuciwszy wędkę zdobycz chwytał w głębinie i zmorę głodu odpędzał ledwo tolerowaną pracą. Przez cały czas ucieczki powstrzymywał się od współżycia z dziewicą Waltharius, sławny bohater” [tłum. P.Ż.]; Cronaca di Novalesa, ks. 2, rozdz. 9, s. 90, z niewielkimi zmianami. Ostatnie zdanie tego passusu wydaje się dwuznaczne. „Continere” może równie dobrze znaczyć „trzymać”, „łączyć”, co „powstrzymywać się”. Nieformalne kontakty seksualne lepiej pasowałyby do statusu zdrajców, zbiegów i złodziei, jaki autor przypisał Walthariusowi i Hilgundzie. Argumenty na rzecz rozumienia „,continere” jako „powstrzymać się” przytacza J.O. Ward, The Function of the Epic in Latin Culture. The ,Waltharius" and Carolingian Attitudes towards Marriage, w: The Epic in History, red. L.S. Davidson, S.N. Mukherjee, Z. Zlatan, Sydney Studies in Society and Culture, Sydney 1994, s. 97-99.

${ }^{85}$ F.B. Parkes, Irony in Waltharius, „Modern Language Notes”, 89, 1974, nr 3, s. 460. 
i Hagana. Za radą tego ostatniego król Franków wycofał się z wąwozu. Następnie obaj zaczaili się na Walthariusa w innym miejscu. W ostatecznym starciu Akwitańczyk odciął Guntherowi nogę, Hagan pozbawił Walthariusa prawej ręki, ale sam stracił oko i część uzębienia. Walczący zaakceptowali remisowy wynik walki. Waltharius odjechał z Hilgundą do Akwitanii, gdzie po ojcu objął tron królewski ${ }^{86}$.

Każdy z uczestników tego potrójnego pojedynku kalectwem zapłacił za jaką́s przewinę ${ }^{87}$. Złe uczynki Gunthera i Hagana zostawiam na boku. Waltharius natomiast okłamał i okradł Attylę, któremu przysiągł wierność. Odkąd sprzeniewierzył się on królowi Hunów niektóre jego działania kojarzą się z zajęciami kobiecymi, podobnie jak i przedmioty, których używa. Ponadto bez udziału Hilgundy ani kradzież, ani ucieczka nie byłyby możliwe. Ona zabrała kosztowności ze skarbca Attyli, ponieważ była jego strażniczką. Ona także zleciła rzemieślnikom wykonanie haczyków i niosła wędkę podczas ucieczki. Wędkowanie i łapanie ptaków wyraźnie wiąże się z antybohaterskim statusem uciekającego Walthariusa.

Najciekawsze przeciwstawienie umiejętności militarnych i chwytania ryb techniką wędkarską można napotkać w opowieści o najeździe króla Arnulfa na Italię w pierwszej księdze Antapodosis Liudpranda z Cremony. Władca wschodniofrankijski jawi się w tekście jako postać ambiwalentna: to najpotężniejszy monarcha Północy, ale powodowany nadmierną żądzą władzy, sprowadził na Morawy straszliwy lud Węgrów, aby pokonać Centebalda (Świętopełka) ${ }^{88}$. Wyprawa italska jest w Antapodosis pasmem niekwestionowanych, wspaniałych zwycięstw Arnulfa, aż do momentu, kiedy wypicie zatrutego napoju doprowadziło króla do paraliżu i zmusiło do odwrotu. Potem spadła na niego ostateczna kara - umarł pożarty przez wszy ${ }^{89}$. Powód interwencji Arnulfa za Alpami był w pełni uzasadniony. Otóż dwaj zaprzyjaźnieni italscy możnowładcy przysięgli sobie, że po śmierci króla Karola podzielą się władzą. Pierwszy, Wido, margrabia Cammerino i Spoleto, miał zasiąść na tronie Franków Zachodnich, a drugi, Berengar, rządzić w Italii. Kiedy plan Widona nie wypalił, margrabia powrócił do swojej marchii i wszczął wojnę z dawnym przyjacielem. Pokonany Berengar obiecał Arnulfowi, że podda Italię jego panowaniu ${ }^{90}$.

Król wschodniofrankijski wyruszył z wielką armią. U jego boku podążał Berengar i na znak swojej wierności niósł tarczę królewską ${ }^{91}$. Arnulf szybko, sprawnie i bezwzględnie zdobywał stawiające mu opór miasta oraz warownie. Po wzięciu szturmem Bergamo kazał powiesić na bramie miejscowego komesa. Na Italię padł blady strach. Wido uciekł na południe, do Cammerino i Spoleto ${ }^{92}$. Nie było miejsca dostatecznie warownego, aby oprzeć się męstwu Arnulfa. W tym momencie opowiadania Liudprand zadał pytanie retoryczne: „Quid autem mirum, cum ipsa civitatum omnium regina, magna scilicet Roma, huius impetum ferre nequiverit? Enimvero dum a Romanis ingrediendi urbem huic fidutia negaretur, convocatos ad sese milites ita convenit" ${ }^{\text {"93 }}$. Arnulf przemówił do swojego wojska wierszem ${ }^{94}$ : „Magnanimi proceres et clares Marte secundo / Arma quibus studium fulvo radiare metallo / Romulidae sueti vacuis quod condere criptis / Sumite nunc animos, vobis furor arma ministret / Non Pompeius adest, non Iulius ille beatus / Qui nostros domuit proavos mucrone feroces / Indolis huius enim summos deduxit

${ }^{86}$ Waltharius, w. 428-1456, s. 74-178. W wersji kroniki z Novalesy opowieść o starciu w wąwozie została drastycznie skrócona. Natomiast szczegółów ostatecznego pojedynku brakuje zupełnie; Cronaca di Novalesa, ks. 2, rozdz. 9, s. 90-100.

87 J. Banaszkiewicz, Złota ręka komesa Żelisława (Gall, II, 25; Kadlubek, II, 24, 26), w: Imagines Potestatis. Rytuaty, symbole i konteksty fabularne władzy zwierzchniej. Polska X-XV w. (z przykładem czeskim i ruskim), red. J. Banaszkiewicz, Warszawa 1994, s. 231-232, 241-242, 245 (przyp. 25).

${ }^{88}$ Liudprandi Cremonensis Opera Omnia, wyd. P. Chiesa, Corpus Christianorum Continuatio Mediaevalis, t. 156, Turnholti 1998, Antapodosis, ks. 1, rozdz. 13, s. 16-17.

89 Por. J. Banaszkiewicz, Podanie o Piaście i Popielu, s. 200-201. J. Banaszkiewicz kładzie zdecydowanie silniejszy nacisk na negatywne cechy Arnulfa.

${ }^{90}$ Liudprandi Cremonensis, Antapodosis, ks. 1, rozdz. 14-20, s. 17-19.

91 Tamże, rozdz. 22, s. 20.

92 Tamże, rozdz. 23-25, s. 20-21.

93 Tamże, rozdz. 25, s. 21: „Cóż zresztą dziwnego, skoro sama królowa wszystkich miast, mianowicie wielka Roma, nie mogła znieść jego zaciekłości? Bowiem kiedy miał już wejść do miasta, Rzymianie odmówili mu zaufania, więc przywoławszy do siebie wojowników, tak się do nich zwrócił" [tłum. P.Ż.].

${ }^{94}$ E. Colonna, Le poesie di Liutprando di Cremona. Commento tra testo e contesto, Bari 1996, s. 62-68. 
ad Argos / Protulit in lucem quem sancta Britannica mater / His torta studium pingues captare siluros / Cannabe, non clipeos manibus gestare micantes"95.

W patetycznej formule królewskiej mowy przed bitwą Liudprand z Cremony przeciwstawił wyćwiczonych we władaniu bronią i oddanych Marsowi wojowników Arnulfa Rzymianom, którzy nie mieli już nic wspólnego ze swoimi świetnymi przodkami. Prawdziwi potomkowie Romulusa, Pompejusza i Cezara już nie żyją albo zostali przeniesieni do Nowego Rzymu przez Konstantyna Wielkiego, syna św. Heleny, pochodzącej z Brytanii. Dla współczesnych Arnulfowi pseudo-Rzymian właściwszym zajęciem jest łapanie tłustych sumów niż walka zbrojna. Lepiej gdyby „królowa wszystkich miast” poddała się królowi wschodnich Franków tak jak to wcześniej uczyniły Werona, Mediolan i Pawia. Liudprand określił dokładniej, w jaki sposób Rzymianie powinni łowić ryby, zamiast podejmować bezsensowną próbę obrony miasta. Kronikarz użył słów „torta cannabe”, a więc połów miał się odbywać za pomocą „skręconej konopi”, czyli konopnym sznurem, zatem - jak trzeba się domyślać - na wędkę ${ }^{96}$ Liudprand zapożyczył zwrot „torta cannabe” z V satyry Persjusza (w. 146), w której uosobiony Zbytek wyrzuca kupcowi podejmującemu wyprawę morską, że dla zysku naraża się na niewygody i m.in. jeść będzie posiłki na linie okrętowej ${ }^{97}$. I właśnie w znaczeniu sznura, do którego przyczepiony musi być haczyk do łowienia ryb, zwrot „torta cannabe” trafił do Antapodosis. Kronikarz uczynił z wędkowania najbardziej dobitny symbol całkowitego upadku militarnej potęgi Rzymu. Słowa włożone w usta króla wschodniofrankijskiego wspiera zresztą opowieść o zdobyciu miasta. Kiedy bohaterscy wojownicy Arnulfa (heroes) rozpoczęli przygotowania do szturmu, nagle spłoszony wojskowymi hałasami zajączek wyskoczył spomiędzy nich i pobiegł w kierunku murów Rzymu. Oblegający odruchowo zaczęli go ścigać. Obrońcy miasta, przekonani, że właśnie następuje atak, uciekli z murów. W ten sposób, właściwie bez walki, Arnulf zajął Rzym ${ }^{98}$.

Można już pokusić się o podsumowanie przytoczonego materiału porównawczego. Za każdym razem wędka łączy się z określonymi cechami i zachowaniami używających jej postaci. Chrétien de Troyes, sądząc po słowach wypowiadanych w powieści przez Percevala, uczynił z Rybaka osobę pełną sprzeczności, króla - nie-króla. Bohaterski junak nazwał go „panem”, ale już chwilę później z dużą łatwością odsądził od czci. Z trudem natomiast przyszło Percevalowi przyjąć do wiadomości królewską godność Rybaka, poświadczoną przez dziewczynę. Niegodne króla zajęcie wytłumaczone jest kalectwem uniemożliwiającym walkę i polowanie, a nawet utratą męskości. Tylko taka żałosna rozrywka pozostała człowiekowi, który przestał spełniać swoją funkcję. Zdaniem Plutarcha, wędkarskie przygody Marka Antoniusza stanowią miarę upadku wielkiego wodza, zdegenerowanego nadmiernym uzależnieniem od Kleopatry i przepychem jej dworu. Dla wzmocnienia efektu ta sama kobieta, która odebrała bohaterowi wojowniczość, uświadomiła mu, że wędkowanie jest odpowiednie dla niej, a pozostaje

95 Liudprandi Cremonensis, Antapodosis, ks. 1, rozdz. 26, s. 21-22: „Pierwsi z dzielnych i najjaśniejsi według Marsa, których zamiłowanie do broni złocistym promienieje metalem. Skoro Romulidzi zdatni do wojny, do próżnych złożeni są podziemi, podnieście się na duchu, niech wściekłość waszej broni służy. Nie ma już Pompejusza, to nie boski Juliusz, który naszych dzikich pradziadów ujarzmił mieczem. Bowiem najlepszych z jego potomków zaprowadził do Argos ten, którego wydała na świat święta brytańska matka. Tych zajęciem łapać tłuste sumy konopnym sznurem, a nie dzierżyć w rękach błyszczące tarcze” [tłum. P.Ż.]. Nic nie wskazuje na to, aby Wincenty Kadłubek znał Antapodosis i mógł przejąć „siluri” od Liudpranda.

96 Tak zinterpretowali „torta cannabe” thumacze Antapodosis na język angielski i rosyjski, którzy zdecydowali się na thumaczenie omowne; The Complete Works of Liudprand of Cremona, thum. P. Squatriti, Washington (D.C.) 2007, s. 62: „curved fishing rod"; Лиутпранд Кремонский, Антаподосис, Книга об Оттоне, Отчет о посольстве в Константинополь, oprac. И.В. Дьяконов, Москва 2006, s. 27: „ловить на удочку”. Wędka pojawiła się również w przekładzie francuskim, hiszpańskim i włoskim E. Colonny, ale we wszystkich wypadkach w wyniku błędnego zrozumienia „torta cannabe” jako „wygiętej trzciny”; Liudprand de Crémone, Oeuvres, tłum. F. Bougard, Sources d'histoire médiévale, t. 41, Paris 2015, s. 110: „la canne recourbée”; La Antapódosis o retribución de Liutprando de Cremona, wyd. P.A. Cavallero Sada, Madrid 2007, s. 25: „caña curvada”; E. Colonna, Le poesie di Liutprando, s. 62: „la ritorta canna”. Chybione omowne thumaczenie włoskie zaproponował P. Chiesa; Liutprando, Antapodosis, tłum. P. Chiesa, Milano 2015, s. 53: „reti intrecciate”.

97 Trzej satyrycy rzymscy, Horacy - Persjusz - Juwenalis, [Persjusz w tłum. J. Sękowskiego], oprac. L. Winniczuk, Warszawa 1958, s. 111.

98 Liudprandi Cremonensis, Antapodosis, ks. 1, rozdz. 27, s. 22. 
przeciwieństwem tego, co imperatorowi wypada czynić, czyli prowadzenia wojen zdobywczych. Waltharius zaczął posługiwać się wędką w momencie, kiedy zszedł z bohaterskiej ścieżki. Łapanie ryb na haczyk (i ptaków w pułapki) jest zajęciem godnym zdrajcy, złodzieja, uciekiniera. Sprowadziło ono na Walthariusa śmiertelne niebezpieczeństwo. Za złe uczynki zapłacił utratą prawej ręki. U Liudpranda mieszkańcy „Romy - królowej miast” postradali wojskowe cnoty swoich przodków. W tym żałosnym stanie pozostaje im raczej łowić sumy, a nie walczyć. Próba obrony miasta skończyła się całkowitym blamażem. Wędkowanie często łączy się z bogactwem. Dwór Króla-Rybaka poraził swoim przepychem Percevala. Antoniusz pławił się w dostatkach Egiptu. Akwitański królewicz zrabował bajeczny skarb Attyli.

Zanim znaczenia wędki, uchwytne w powieści o Percevalu, żywocie Antoniusza, poemacie o Walthariusie i dziele Liudpranda z Cremony, odniosę do Gallowego opowiadania, chciałbym powrócić do „prostoty” przypisanej Rusinom i ich królowi. Przypominam, że W. Polak starał się rozpoznać sens pojęcia „simplicitas” we wzmiance o Sobiesławie, pojawiającej się w rozdziale 21. księgi trzeciej kroniki Anonima, i doszedł do przekonania, że oznacza ono naiwną głupotę 9 . Moim zdaniem „prostota" u Galla może być źle oceniana tylko z jednego, wojskowego punktu widzenia. Postaram się tego dowieść, pokazując nieco szerzej kontekst, w którym w kronice funkcjonuje postać najmłodszego z ciotecznych braci Bolesława Krzywoustego. Zaangażowanie polskiego władcy w walki o tron w Pradze to jeden z wielkich tematów ostatniej księgi kroniki. Najpierw, w rozdziale szesnastym, kończąc opowieść o najeździe niemieckim na Polskę, kronikarz dał obszerną charakterystykę czeskiego księcia Świętopełka, który nie tylko posiłkował Niemców podczas wyprawy, ale miał być nawet głównym podżegaczem wojennym. Wcześniej, kierując się żądzą władzy, wydarł Czechy z rąk Borzywoja, czyli najstarszego z ciotecznych braci Bolesława III. Świętopełk poniósł karę za wszystkie swoje złe uczynki. W trakcie odwrotu z Polski zabił go ktoś z jego własnych ludzi ${ }^{100}$. Na wieść o tym Krzywousty natychmiast wyprawił się za Sudety i przywrócił tron czeski Borzywojowi ${ }^{101}$. Czesi jednak szybko pozbyli się legalnego władcy, wybierając jego średniego brata ${ }^{102}$ (Władysława).

W tym momencie Gall Anonim wprowadził postać Sobiesława, stwierdzając, że Borzywój: „Tertium quoque fratrem habebat, etate quidem minorem, probitate non inferiorem, quem dux Bolezlaus in fidelitate fratris persistentem in Polonia retinebat, eique calumpniandi maioris fratris honorem et consilium et auxilium impendebat" ${ }^{103}$. Zacność i wierność Sobiesława zostały skonfrontowane z przewrotnością i zdradą Czechów, a nawet nieuczciwością samego cesarza, który uwięził wygnanego Borzywoja, odbierając mu tym samym możliwość odzyskania należnej godności. Bolesław Krzywousty zdecydował się więc na kolejną wyprawę zbrojną do Czech. Gall przedstawił ją jako wielki pochód wojenny, dalece świetniejszy od marszu Hannibala na Italię. Polski książę wkroczył na terytorium wroga, broniąc słusznych praw Borzywoja. Szedł wraz z uszykowanym, ogromnym wojskiem, z podniesionymi chorągwiami, przy akompaniamencie trąb i bębnów. Czesi wychodzili dużymi oddziałami z grodów. Polacy, idąc im na spotkanie, palili „suburbia” owych umocnionych miejsc. „Frater vero Borivoy minimus, quem predixi, predas capi, incendia fieri, terram destrui, Bolezlauo supplicans prohibebat, quia regnum acquirere sine bello puerili simplicitate verbis traditorum sine victoriis se credebat”"104. „Chłopięca prostota" polegała zatem na naiwnej wierze w zapewnienia zdradzieckich Czechów oraz na braku

99 W. Polak, Kronika Galla Anonima a pochodzenie rodu Awdańców, s. 411.

${ }^{100}$ Gall Anonim, ks. 3, rozdz. 16, s. 142-143.

${ }_{101}$ Tamże, rozdz. 17, s. 143-144.

102 Tamże, rozdz. 20, s. 145.

103 Tamże, s. 145; pol. tłum. za: Grodecki/Plezia, s. 148: „Miał także trzeciego brata, wiekiem wprawdzie młodszego, ale nie ustępującego mu pod względem zacności; on to dochował bratu wierności, a książę Bolesław utrzymywał go w Polsce i dostarczał mu pomocy i rady celem podkopywania władzy starszego brata [Władysława - P.Ż.]”.

104 Gall Anonim, ks. 3, rozdz. 21, s. 147; pol. tłum., nieco przeze mnie zmodyfikowane (modyfikację zaznaczam pogrubieniem) za: Grodecki/Plezia, s. 149: „A najmłodszy zaś brat Borzywoja, o którym wspominałem, błagając Bolesława nie dawał mu brać łupów, wzniecać pożarów i niszczyć kraju, bo z chłopięcą prostotą wierzył, [ufając] słowom zdrajców, że może pozyskać królestwo bez wojny i bez zwycięstw". 
zrozumienia dla konieczności zbrojnej przemocy. Sobiesław łudził się, że legalnego władcę można restytuować bez rozlewu krwi, pożogi i grabieży oraz nie podejrzewał zdrady. „Chłopięca prostotę” najmłodszego brata Borzywoja łączy więc z ,prostotą” króla Rusinów niechęć do działań wojennych czy też nieumiejętność podjęcia ich w sposób odpowiedni.

W Gallowym opowiadaniu o wyprawie Bolesława Chrobrego na Kijów ruski monarcha przedstawiony jest jako niewłaściwy człowiek w niewłaściwej sytuacji. Znakiem tego qui pro quo kronikarz uczynił wędkę. Król Rusinów w swej prostocie nie wiedział, że dał powód do wojny. Ukazanie go z wędką w ręku uruchamia cały szereg skojarzeń. Opływający w dostatki władca-wędkarz nie nadaje się na obrońcę swojego kraju, ponieważ zastawia niegodną pułapkę na bezbronne ryby, praktykuje sztukę, która zaprzecza męskości i oznacza całkowity brak kwalifikacji militarnych. Czy wizerunek ruskiego monarchy jest elementem „kolorytu orientalnego”? Nie bardzo, skoro tymi samymi środkami pokazany został upadek Króla-Rybaka, Walthariusa z Akwitanii, a nawet Rzymian.

Jeszcze bardziej kłopotliwe wydaje się branie ruskiego króla z wędką za element „świata na opak”. Gallowy „prosty wędkarz” nawiązuje do pewnego typu postaci, która nie jest jedynie „odwrotnością" Bolesława Chrobrego. Król Rusinów ściągnął na siebie nieszczęście, obrażając i prowokując wielkiego, wojowniczego bohatera. Dokładnie tak samo rysuje się w Antapodosis wina Rzymian, którzy, utraciwszy dawną militarną świetność, nierozsądnie odmówili Arnulfowi wstępu do miasta. Poza sferą wojskowo-męsko-heroiczną wędka może się wręcz kojarzyć z niemilitarną mocą. Kleopatra, dla której łapanie ryb na haczyk - zdaniem Plutarcha - jest zupełnie odpowiednim zajęciem, całkowicie rozmiękczyła Antoniusza, twardego i brutalnego żołnierza. Ten, kto miał panować nad Egiptem, stał się „niewolnikiem" egipskiej królowej. Nie tylko kobiecość, ale i sacrum dobrze łączy się z wędką. Chrétien de Troyes rekompensował Królowi-Rybakowi rycerską dysfunkcję świętymi przedmiotami: Graalem i krwawiącą włócznią, wreszcie ojcem żywiącym się wyłącznie Hostią. Liudprand z Cremony, opowiadając o zdobyciu Rzymu przez Arnulfa, nie omieszkał przypomnieć o ciele św. Piotra spoczywającym w mieście ${ }^{105}$. Łapanie ryb na haczyk kala tylko wojowników albo tych, którzy powinni czy też usiłują nimi być.

Szczególnie dobrze tę zasadę ilustruje opowieść o Wandzie w Kronice wielkopolskiej. Kronikarz wielkopolski w charakterystyczny dla siebie sposób wzbogacił wywodem etymologicznym historię wziętą od mistrza Wincentego. Młodszy syn Kraka, po zabiciu starszego brata, ,Solusque sine prole decessit sola sorore Wøda nomine que latine hamus nominatur remanente. Scribitur namque tam decora et grata aspectu fuisse, quod omnes ipsam intuentes in amorem sui suo aspectu speciosissimo attrahebat. Unde ex hoc Wøda, id est hamus, extitit nominata" ${ }^{106}$. Komentarz ten poprzedza przeróbkę Kadłubkowej anegdoty o odparciu najazdu Alemanów na Polskę. W wersji Kroniki wielkopolskiej Wanda, gardząc małżeństwem, umiejętnie rządziła królestwem. Wieść o jej urodzie doszła do uszu króla Alemanów, który prośbami i darami bezskutecznie starał o jej rękę. W końcu postanowił zbrojnie zmusić królową Lechitów do uległości. Wanda odważnie wyszła mu naprzeciw ze swoimi ludźmi. Aleman, zobaczywszy ją, stracił wojowniczą moc oraz wrogie zamiary i z powodu wzgardzonej miłości popełnił samobójstwo. Z pożegnalnej mowy nieszczęśliwie zakochanego wynika, że Wanda była pogańską kapłanką, rozkazującą morzu, ziemi i powietrzu. Alemanowie poddali się władzy królowej. Wanda wróciła do kraju i złożyła się bogom w ofierze dziękczynnej, rzucając się do Wisły ${ }^{107}$.

W Kronice wielkopolskiej piękna, oczarowująca wszystkich wkoło kobieta, porównana została do wędki. To porównanie ma tak wielką moc, że daje imię bohaterce. Wanda-Węda dzięki swoim kobiecym przymiotom potrafiła całkowicie rozbroić, rozmiękczyć, poddać swojej władzy potężne wojsko

105 Liudprandi Cremonensis, Antapodosis, ks. 1, rozdz. 27, s. 22.

${ }^{106}$ Kronika wielkopolska, wyd. B. Kürbis, w: MPH s.n., t. 8, Warszawa 1970, rozdz. 1, s. 8. Polski przekład, nieco przeze mnie zmodyfikowany (zmiany zaznaczam pogrubieniem), za: Kronika wielkopolska, tłum. K. Abgarowicz, wstęp i kom. B. Kürbis, Warszawa 1965, s. 56: „sam umarł bezpotomnie, tak że została jedyna siostra, imieniem Węda, co na łacinę przekłada się: 'hamus', czyli ‘wędka'. Piszą bowiem, że tak była piękna i miłego wejrzenia, że uroczym swym wyglądem wszystkich patrzących na nią pociągała do miłowania; stąd nazwano ją Wędą, to jest wędką".

107 Kronika wielkopolska, rozdz. 1, s. 9. 
Alemanów ${ }^{108}$. Tak uformowana narracja ciekawie koresponduje z Gallową „fabułką” o królu Rusinów, nieznana chyba kronikarzowi wielkopolskiemu, który, pisząc o zdobyciu Kijowa przez Chrobrego, okoliczności zaczerpnął z kroniki Kadłubka, ale pominął występujący tam motyw wędki. U Anonima władca wędkujący w obliczu najazdu kogoś, komu odmówił ręki siostry, błaźni się i przegrywa, natomiast „władczyni-wędka” niemilitarną siłą swojego uroku pokonuje niechcianego adoratora i jego armię. Punktem wyjścia etymologii imienia Wandy w Kronice wielkopolskiej jest - jak się zdaje - Owidiuszowe porównanie uwodzenia do łapania ryb na haczyk ${ }^{109}$. Myśl tę podchwycił Izydor z Sewilli, wyjaśniając pochodzenie słowa „przyjaciel”: „Amicus ab hamo, id est, a catena caritatis; unde et hami quod teneant" ${ }^{\prime 10}$, a w drugiej połowie XII w. nawiązywał do niej Andreas Capellanus i inni autorzy ${ }^{111}$. Jednak w Kronice wielkopolskiej - co w kontekście Gallowego króla Rusinów jest znacznie ważniejsze - miłosne „wędkowanie” zestawione zostało ze zbrojną przemocą. Piękna i mądra „kobieta-wędka" może odmówić swojej ręki i umie zwycięsko, ale niemilitarnie powstrzymać próbę narzucenia małżeństwa siłą.

Pozytywną postacią jest także św. Zenon, biskup Werony. Tradycję hagiograficzną zapoczątkowuje kazanie, które napisał w VIII w. Coronatus Notarius. Święty mieszkał w klasztorze nieopodal Werony. Pewnego razu poszedł nad rzekę Adygę łowić ryby. Tam zobaczył naprzeciw siebie jakiegoś człowieka, siedzącego na wozie zaprzężonym w woły, który poruszał się w wodzie z taką prędkością, że od razu znać było diabelską sprawę. Święty mąż podniósł rękę, wielokrotnie uczynił znak krzyża i kazał Szatanowi wracać, zabraniając mu krzywdzenia ludzi, których Bóg stworzył. Diabeł zniknął niczym piana, ale krzykiem, jakby z drugiego brzegu, oświadczył, że gotów jest udać się gdzie indziej. Biskup jeszcze raz podkreślił, że Pan nie pozwala demonowi działać przeciwko swoim sługom. Zły duch podążył w związku z tym do pałacu pogańskiego cesarza Galiena i owładnął jego jedyną córką. Przez jej usta powiedział, że nie wyjdzie, dopóki nie nakaże mu tego biskup Zenon. Władca wysłał ludzi na poszukiwania świętego. Ten zaś siedział na skale przy klasztorze i łowił ryby w rzece, kiedy nadeszli. Wysłannicy Galiena rozpoznali w nim człowieka Bożego i poprosili o wskazanie im Zenona. Biskup przedstawił się i na wieść, że cesarz wzywa go do pałacu, zapytał: „Quid meam vult humilitatem videre imperator, qui omnium Christianorum inimicus esse non desistit?"112. Żołnierze wyjaśnili, że powodem jest opętanie córki Galiena. Zenon poszedł i wygnał demona z dziewczyny. Widząc to, władca zdjął koronę królewską (coronam regalem) ze swojej głowy i oddał świętemu, twierdząc, że nie ma odpowiedniejszego daru dla lekarza, który uzdrowił jego córkę. Na widok cudu wiele osób w pałacu nawróciło się na chrześcijaństwo. Biskup oddał koronę biednym, a następnie, za zgodą cesarza, obalił pogańskie idole w Weronie i konsekrował tam kościół.

Coronatus Notarius nie sprecyzował, jak Zenon łowił ryby, ale twórcy brązowych, romańskich drzwi kościoła San Zeno w Weronie zilustrowali niektóre sceny z żywota biskupa i przedstawili świętego z wędką (zob. ilustracja), podczas rozmowy z wysłannikami Galiena ${ }^{113}$. Łapanie ryb, w sytuacji gdy zagraża Szatan, a więc przeciwnik, którego nie można pokonać militarnie, okazuje się całkiem odpowiednim zajęciem dla kogoś, kto umie go ujarzmić. W opowiadaniu Galla Anonima wędka-atrybut podkreśla więc, w jak nieodpowiedniej sytuacji znalazła się dzierżąca ją postać. Łowienie ryb pozwala

108 J. Banaszkiewicz, Polskie dzieje bajeczne Mistrza Wincentego Kadtubka, wyd. 2, Wrocław 2002, s. 66-67.

109 Owidiusz, Sztuka kochania, tłum. E. Skwara, Wrocław 2016, ks. 1, w. 393, s. 90; J. Berchtold, L'échiquier absent, s. 116-117.

${ }^{110}$ Isidorus Hispalensis, Etymologiarum siue Originum libri XX, wyd. W.M. Lindsay, Oxford 1911, ks. 10, par. 5: „Przyjaciel od wędki, to jest: od łańcuchów miłości; i stąd, że wędki chwytają" [tłum. P.Ż.].

111 D.A. Monson, Andreas Capellanus, Scholasticism and the Courtly Tradition, Washington (D.C.) 2005, s. 22-23; D. Seidenspinner-Núñez, The Allegory of Good Love. Parodic Perspectivism in the „Libro de Buen Amor”, University of California Publications in Modern Philology, t. 112, Berkeley-Los Angeles-London 1981, s. 48-49, 57-58.

112 De Zenonis vita sermo Coronati Notarii, w: Patrologia Latina, t. 11, wyd. J.-P. Migne, Paris 1845, kol. $200-202$ (cyt. zdanie w kol. 202): „Dlaczego chce widzieć moją pokorę cesarz, który nie przestał być wrogiem wszystkich chrześcijan?” [tłum. P.Ż.].

113 F. Butturini, Il segno e il tempo nella porta bronzea di san Zeno di Verona, fot. P. Chasseur, wstęp J.-P. Jouvet, Firenze 1982, s. 29-30 i tabl. 41 


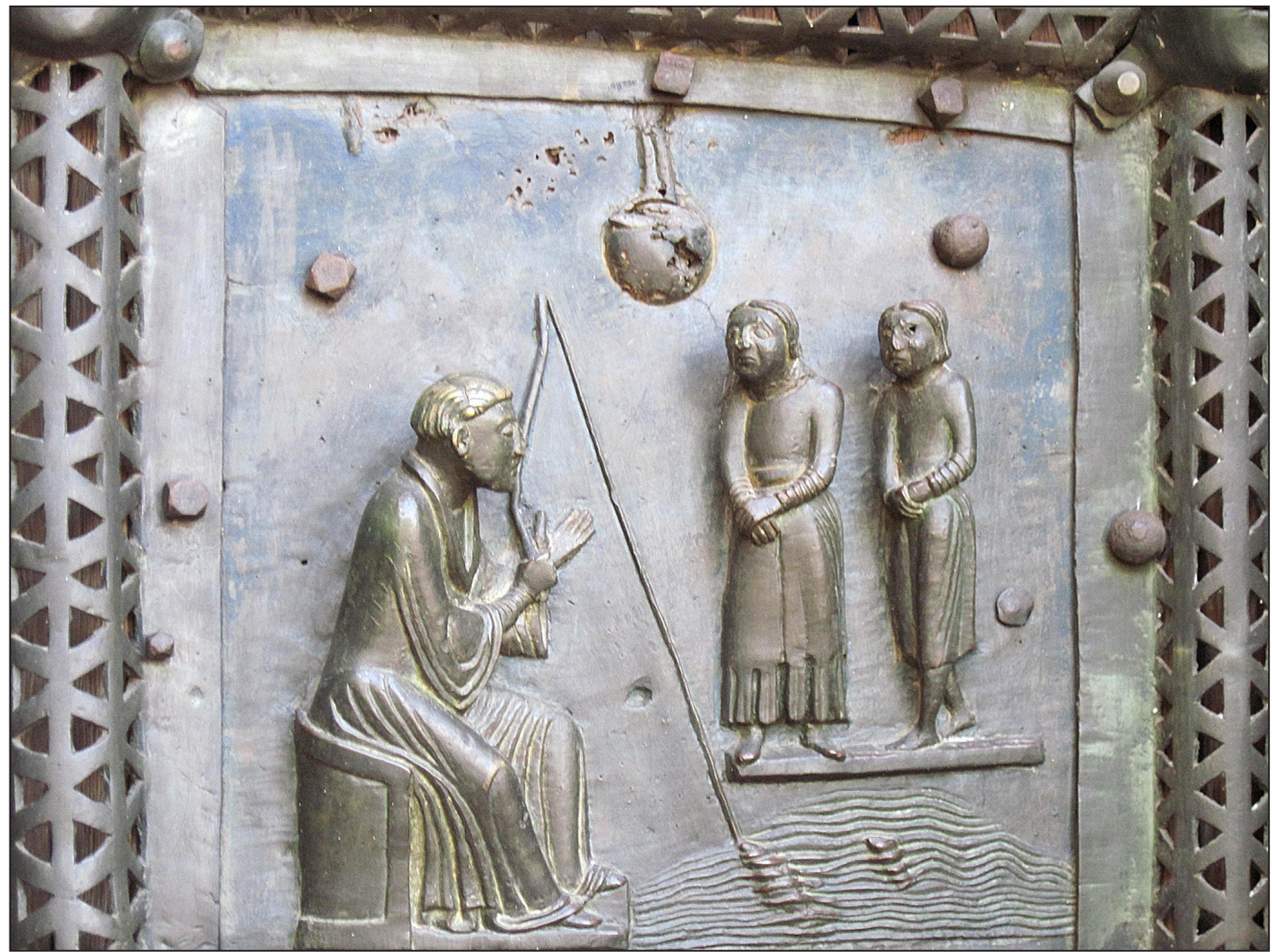

jaskrawiej ukazać militarną znikomość króla Rusinów. On sam doprowadził do wojny, której prowadzić nie był w stanie. „Fabella de piscatore” obrazuje też konfrontację dwóch społeczności: ruskiej - pełnej prostoty i bogactwa, miękkiej, w pewnym sensie kobiecej, rządzonej przez króla takiego samego jak ona oraz polskiej - wojowniczej, zdobywczej, prowadzonej przez władcę, którego wojenny heroizm pozostaje niedościgłym wzorcem dla jego wojowników. Władca tej pierwszej, zgodnie z porządkiem rzeczy postulowanym przez Galla, powinien był oddać kobietę królowi Bolesławowi. Wówczas pozostałby w zgodzie ze swoją naturą.

\section{A fishing rod of the king of the Ruthenians (Gallus Anonymus, Book I, chapt. 7)}

Summary: The purpose of the article is an attempt to solve the following question: why did Gallus Anonymus present the king of the Ruthenians fishing with a fishing rod at the very moment of Boleslaw Chrobry's attack, which inflicted a catastrophic defeat upon Rus'? In the Chronicle the king of the Ruthenians is presented as an unwarlike and cowardly man, but this in itself does not explain, why the chronicler placed him in a boat, fishing. The matter is not made clear by the medieval adaptations of this anecdote by Wincenty Kadłubek and Jan Dlugosz. None of them understood the sense Gallus gave to the motif of fishing rod and both changed its meaning. Also the cases of fishing described in the Bible have a different character altogether. But a useful context is given by motif of fishing rod and fishing people in stories certainly unknown to Gallus Anonymus. The article presents a choice of texts where fishing refers to military matters and brings disgrace to the king or hero: Le roman de Perceval ou le conte du Graal by Chrétien de Troyes (the Fisher King), Plutarch's Life of Antony, Waltharius, the story about Arnulf conquering Rome in the Antapodosis by Liudprand of Cremona. The comparison makes it possible to say that in the medieval literature the fishing rode quite often plays the role of anti-attribute that given to a king or warlike hero becomes a clear sign of the lacked or lost ability to command the army and fight war, or of the betrayal of the honour of a brave soldier. On the other hand, the association with fishing or with using a fishing rod is not disgraceful for people who do not aspire to military functions or actions, as illustrated by the examples of Wanda-Węda in the Chronica Poloniae maioris (Chronicle of Greater Poland), and of Saint Zeno of Verona in De Zenonis vita sermo Coronati Notarii. 
Notka o Autorze: dr hab. Paweł Żmudzki, adiunkt w Zakładzie Nauk Pomocniczych i Metodologii Historii Instytutu Historycznego Uniwersytetu Warszawskiego.

Author: dr hab. Paweł Żmudzki, assistant professor in Department Auxiliary Sciences of History and Methodology, Institute of History, University of Warsaw.

Instytut Historyczny

Uniwersytet Warszawski

Krakowskie Przedmieście 26/28

00-927 Warszawa

e-mail: p.zmudzki@uw.edu.pl

\section{Bibliografia}

\section{Źródta}

Anonim tzw. Gall, Kronika polska, tłum. R. Grodecki, oprac. M. Plezia, wyd. 7, Wrocław-Warszawa-Kraków 1999 Anonima tzw. Galla kronika czyli dzieje książąt i władców polskich, wyd. K. Maleczyński, MPH s.n., t. 2, Kraków 1952

Biblia sacra iuxta Vulgatam versionem, wyd. 3, Stuttgart 1985

Chrétien de Troyes, Le roman de Perceval ou le conte du Graal, wyd. K. Busby, Tübingen 1993

Chrétien de Troyes, Percewal z Walii czyli opowieść o Gralu, tłum. A. Tatarkiewicz, w: Arcydzieła francuskiego średniowiecza, wybór M. Żurowski, oprac. Z. Czerny, Warszawa 1968

De Zenonis vita sermo Coronati Notarii, w: Patrologia Latina, t. 11, wyd. J.-P. Migne, Paris 1845, kol. 200-203

Gallus Anonymus, Gesta Principum Polonorum, thum. i oprac. P.W. Knoll, P. Schaer, wstęp T.N. Bisson, Budapest-New York 2003

Ioannis Dlugossii Annales seu Cronicae incliti Regni Poloniae, ks. 1-2, wyd. J. Dąbrowski i in., Varsavia 1964

Kronika wielkopolska, wyd. B. Kürbis, MPH s.n., t. 8, Warszawa 1970

Liudprandi Cremonensis Opera Omnia, wyd. P. Chiesa, Corpus Christianorum Continuatio Mediaevalis, t. 156, Turnholti 1998

Mistrza Wincentego zwanego Kadlubkiem kronika polska, wyd. M. Plezia, MPH s.n., t. 11, Kraków 1994

Plutarchi vitae (17): Demetrius et Antonius, red. K. Ziegler, Lipsiae 1915

Waltharius, wyd. G. Vogt-Spira, Stuttgart 1994

\section{Opracowania}

Banaszkiewicz J., Atrybuty i społeczne „ordines”. Kilka obrazków z X-XI wieku, w: tenże, Trzy po trzy o dziesiatym wieku, Kraków 2014, s. 221-240

Banaszkiewicz J., Młodzieńcze gesta Bolesława Krzywoustego, czyli jak zostaje się prawdziwym rycerzem $i$ władca, w: tenże, Takie sobie średniowieczne bajeczki, wprow. M. Tomaszek, Kraków 2012, s. 517-525

Banaszkiewicz J., Podanie o Piaście i Popielu. Studium porównawcze nad wczesnośredniowiecznymi tradycjami dynastycznymi, wyd. 2, Warszawa 2010

Banaszkiewicz J., Polskie dzieje bajeczne Mistrza Wincentego Kadlubka, wyd. 2, Wrocław 2002

Butturini F., Il segno e il tempo nella porta bronzea di san Zeno di Verona, fot. P. Chasseur, wstęp J.-P. Jouvet, Firenze 1982

Cetwiński M., ,Rex insulsus” $i$,parasitis exercitus”, czyli pycha Rusina ukarana (Gall, I, 10; Kadtubek, II, 12), w: Europa Środkowo-Wschodnia. Ideologia, historia a społeczeństwo. Księga poświęcona pamięci profesora Wojciecha Peltza, red. J. Dudek, D. Janiszewska, U. Świderska-Włodarczyk, Zielona Góra 2005, s. 323-334

Colonna E., Le poesie di Liutprando di Cremona. Commento tra testo e contesto, Bari 1996

Corcoran T.H., Roman Fishermen, „The Classical World”, 56, 1963, nr 4, s. 97-102

Gronowska A., Fabuly rycerskie w „Gesta ducum sive principum Polonorum” Galla Anonima na tle wybranych przyktadów piśmiennictwa średniowiecznego (do końca XIII w.), Warszawa 2010, praca doktorska obroniona na Wydziale Polonistyki UW

Hoffmann R.C., Fishing for Sport in Medieval Europe. New Evidence, „Speculum”, 60, 1985, nr 4, s. 877-902

Kollinger K., Polityka wschodnia Bolestawa Chrobrego (992-1025), Wrocław 2014 
Labuda G., Rozwój zachodnioeuropejskiego eposu o Walterze, w: tenże, Źródła, sagi i legendy do najdawniejszych dziejów Polski, Warszawa 1961, s. 266-276

Marx J., La légende arthurienne et le Graal, Genève 1996 (reprint wyd.: Paris 1952)

Plezia M., Kronika Galla na tle historiografii XII wieku, Kraków 1947

Polak W., Kronika Galla Anonima a pochodzenie rodu Awdańców, w: Peregrinatio ad veritatem. Studia ofiarowane profesor Aleksandrze Witkowskiej OSU z okazji 40-lecia pracy naukowej, red. U. Borkowska, C. Deptuła, R. Knapiński, Z. Piłat, E. Wiśniowski, Lublin 2004, s. 401-418

Żmudzki P., Władca $i$ wojownicy. Narracje o wodzach, drużynie $i$ wojnach $w$ najdawniejszej historiografii Polski i Rusi, Wrocław 2009 